\title{
COLUMN
}

\section{The Tooth of Time: The North American Cordillera from Tanya Atwater to Karin Sigloch}

\author{
Paul F. Hoffman \\ 1216 Montrose Ave., Victoria, BC \\ V8T $2 \mathrm{~K} 4$
}

I remember the first time I met Tanya Atwater. She was still a graduate student at Scripps Institution of Oceanography, but over a year had passed since her paper came out on the San Andreas Fault, arguably the best paper ever written on continental geology (Atwater 1970). I was reminded of our meeting a few months ago, during a talk I heard at the Pacific Geoscience Centre in Sidney, BC.

The plate tectonic revolution was a great leveller: everyone found themselves in the same boat, regardless of age or experience. Yet, having come from one dead orogenic belt, the central Appalachians, to study another one, six times older, prudence urged me to see a living orogen first-hand. So I eagerly accepted an offer-GSC granting leave-without-pay-to teach classes for 9 months at UCSB (University of California - Santa Barbara), then a hotbed of igneous and California geology. The geology department had been built up by Aaron Waters, who brought from Johns Hopkins the tradition of regular weekend field trips for incoming graduate students. John Crowell and Art Sylvester led trips to the San Andreas Fault zone and the Salton Sea; Cliff Hopson, the Coast Range ophiolites and the Sierra Nevada batholith; R.V. Fisher and Bill Wise, the Cenozoic volcanic fields; and Pres Cloud, the Death Valley area. Yet all the trips had one thing in common: sooner or later, at every stop, the talk would turn to Tanya. Tanya says this and Tanya says that. The trip leaders would get in a tizzy, like actors handed a new script at show time. If anyone was upset because Tanya was a woman in a man's game, they didn't say so, but a marine geophysicist interpreting the complexities of onshore California geology was something else. For my part, I hadn't the foggiest notion who this Tanya person was, but I inferred that she must be a pretty formidable character.

Returning from one of the last trips of the year, we pulled off the coastal highway west of Ventura to examine an upturned section of Upper Pliocene turbidites. In the 1930's, an enterprising young micropaleontologist had compared Plio-Pleistocene foraminifera in the subsurface of the Ventura Basin with species living today off the California coast. He found that the graded sandstone beds carry reworked and indigenous shallowwater, even lagoonal forms, while the shales have exclusively indigenous forams similar to those found today at water depths of 300-600 m (Natland 1963). He had been ridiculed for suggesting that the sandstones and associated gravels were physically transported to deeper water, then thought to be the reserve of strictly fine-grained deposits, but after the turbidite revolution of 1950 (Kuenen and Migliorini 1950), Manley Natland became a legend in sedimentology (Walker 1973).
Not long after, he became legendary for a different reason. As a Richfield Oil Corporation geologist, Natland proposed that detonating up to 100 underground nuclear devices (atomic bombs) might allow Athabasca Tar Sands oil to be extracted by conventional means. A pilot project outside Fort McMurray (Project Cauldron, later renamed Project Oilsand), backed by the government of Alberta, received federal government approval following the Conservative landslide under John Diefenbaker in 1958. When Lester Pearson's Liberals were elected in 1963, the project was quietly cancelled in line with Canada's policy of nuclear non-proliferation. Four decades later, tar sands oil production would become a reality, not through nuclear technology but through $\$ 80$-abarrel oil.

Given what had followedKennedy's assassination, Civil Rights, Viet Nam, Richard Nixon-our thoughts were not about tar sand when we ran into another group of geologists as we left the outcrop. Even then, a Berkeley hippy with beads, long curly hair and a flower-print dress, stood out in a group of geologists. She was about a year younger than I and was at least 7 months pregnant. When she talked, effervesced would be a more apt description, she giggled and flapped her hands. Before we parted, John Crowell turned, beaming, and said, "Paul, meet Tanya Atwater".

Tanya grew up in Los Angeles, where her mother was a botanist and her father an engineer. She loved geometry in school and thought of becoming an artist until age 15 , when 
the launch of the Sputnik drew her attention to science and engineering. She went to MIT (Massachusetts Institute of Technology), where women could enroll in those fields, and was in her fifth major in three years when she "accidentally took a physical geology course [taught by petrologist W.H. Dennon] and was hooked immediately" (Atwater 2001). Field camp in Montana banished any doubts and, eager to return to California where "rocks don't spend most of their time covered by green or white stuff", she transferred to UC - Berkeley in 1963, graduating two years later in geophysics. The hippy scene was in its early heyday.

Back east again as a summer intern in 1965, she saw Tuzo Wilson demonstrate transform faults when it was a new concept (Coode 1965; Wilson 1965). The next year, working as a technician at the Geophysics Institute in Santiago, Chile, she heard Jim Heirtzler report on a new magnetic profile obtained across the Pacific-Antarctic Rise (Pitman and Heirtzler 1966). The Eltanin-19 profile remains the longest, cleanest and most symmetrical of any spreading ridge in the world (Atwater 2001), convincing even Lamont-

Doherty's Director Maurice Ewing and other skeptics that sea-floor spreading was a reality (Glen 1982; Le Pichon 1986). Like its continuation, the East Pacific Rise, it had been thought a poor candidate for sea-floor spreading because it lacked an axial rift valley.

Historians mark 1967 as the year the plate tectonics revolution ended, but for marine geophysicists it was really just the beginning. Tanya arrived at Scripps in January, metaphorically as well as literally. The place was in ferment. Fred Vine had stopped by in December, presenting his synthesis of symmetrical magnetic anomaly profiles documenting seafloor spreading in all the major ocean basins back to $10 \mathrm{Ma}$ (Vine 1966). This was a personal as well as scientific triumph for Vine because the original conjecture (Vine and Matthews 1963), linking sea-floor magnetic anomalies to geomagnetic reversals through seafloor spreading, preceded the discovery of symmetrical profiles. Tanya was snatched up by John Mudie, who was developing an instrument package that could be towed close to the bottom during an upcoming cruise to the Gorda Rift, north of the Mendocino Fracture Zone. He needed a capable student to work up the data and he was willing to fight to have a woman allowed on board the cruise. The highresolution survey showed that active volcanism was limited to the axial rift valley and that the ridge crests were not volcanic in origin but structural uplifts flanked by inward-dipping normal faults. The resulting report likely satisfied her orals committee: it was published as the lead article in Science (Atwater and Mudie 1968). The years 1967-68 were a watershed. Tuzo Wilson's concept of mobile rigid plates (Wilson 1965) had been given mathematical expression in terms of Euler rotations on a sphere, allowing the concept to be tested quantitatively (Bullard et al. 1965; McKenzie and Parker 1967; Morgan 1968; Le Pichon 1968; see also Le Pichon 1991; Frankel 2012a, b). Breaking ranks with their elders, three young seismologists assembled comprehensive independent support for plate tectonics (Isacks, Oliver and Sykes 1968)—rescuing seismology from ignominy for stonewalling mantle convection and continental drift. Perhaps most important, magnetic profiles covering large parts of the Pacific, South Atlantic and Indian oceans, which Lamont-Doherty vessels for years had been systematically acquiring for no apparent reason, were compiled and interpreted in terms of sea-floor spreading (Dickson et al. 1968; Le Pichon and Heirtzler 1968; Pitman et al. 1968), using a common magnetic chronology calibrated by simple extrapolation back to $85 \mathrm{Ma}$ (Heirtzler et al. 1968).

The distinctive fracture zones of the eastern Pacific were discovered and named by Bill Menard at Scripps. His intimate familiarity with the topography of the deep Pacific seafloor was unrivalled, but before the concept of sea-floor spreading, all that knowledge had been powerless to decipher the geologic history of the Pacific basin (Menard 1964). In 1968, Menard had a draftswoman transfer by hand all of the magnetic profiles from Scripps cruises in the northeast Pacific onto a single map. The job took weeks, with the result that every night, when drafting stopped, new and often surprising features had emerged. Tanya gravitated to Menard's group and soon found that she and Menard shared a common trait- the need to discuss geologic structures with pencils on scraps of paper (Atwater 2001). Menard was troubled that the larger Pacific fractures zones have disturbed regions of structural complexity, where their traces deviate from small circles in seeming defiance of a cardinal rule of plate tectonics. However, the rule that transform faults follow small circles with respect to the rotation pole between two plates is valid only if the rotation pole remains fixed. In a system with multiple plates, competing in a struggle for existence, rotation poles must shift from time to time with consequent changes in sea-floor spreading direction. In a series of papers, the patriarch and the graduate student showed that the disturbed zones are not random but are systematically related to episodic changes in sea-floor spreading direction (Menard and Atwater 1968, 1969; Atwater and Menard 1970). They inferred that a particularly marked change in spreading direction had occurred $\sim 55 \mathrm{Ma}$, according to the Heirtzler time scale (Heirtzler et al. 1968), close to the age of the subsequently described bend in the HawaiiEmperor seamount chain. From Menard, Tanya also learned that any new concept, to gain attention, needs a name that clicks (Atwater 2001). Soon, everyone was talking about "leaky" transform faults (Menard and Atwater 1969).

Marine and continental geology were still worlds apart in the 1960's. Tanya's interest in the San Andreas Fault, a continental structure, grew out of a conversation with Dan McKenzie, who visited Scripps in the Fall of 1967 to work on a paper with Bob Parker, a geophysical inverse theorist newly arrived from Cambridge (Atwater 2001; Frankel 2012b). The two Englishmen came to beer-hour one evening in an ebulliant mood and began expounding on the San Andreas and Queen Charlotte faults as transform faults, which along with the Alaska-Aleutian subduction zone accommodate right-lateral motion between the Pacific and North American "plates". Hoping to trip them up"They were acting so smug"-Tanya 
instinctively grabbed for Dan's pencil to add the Mendocino Fracture Zone to his sketch map. The Mendocino intersects the physiographically less impressive San Andreas Fault at a $\sim 45^{\circ}$ angle and obviously does not line up with the proposed motion. Dan held up his hand and calmly drew in a third plate boundary, intersecting the other two at a common point (Fig. 1). Chagrined, Tanya realized that the existence of a third plate, converging with North America, would allow the slip vectors between the three plates to sum to zero-permitting simultaneous right-slip on the Mendocino and San Andreas faults, and subduction in the gap between the San Andreas and Queen Charlotte faults. The critical third plate is being created at the Gorda-Juan de Fuca ridge (Vine and Wilson 1965), which she was then studying with John Mudie.

McKenzie and Parker had reason to be cocky. Dan was of the opinion that seismic slip vectors, determined from earthquake first motions, would prove more useful in tectonics than principal stress axes, preferred by seismologists. He remembered Teddy Bullard's explicit use of Euler's theorem in an iconic pre-drift restoration of continents around the Atlantic (Bullard, Everett and Smith 1965). The theorem states that any instantaneous motion on a spherical surface can be specified in terms of a rotation pole and a rate of rotation. He reasoned that, in theory, slip vectors along the Pacific-North America plate boundary should parallel small circles (lines of latitude) with respect to the rotation pole for instantaneous relative motion between the two plates. The inverse problem dawned on him more slowly: using seismic slip vectors as a test of the rigidity of the plates, the central premise of plate tectonics (Wilson 1965). Bob Parker had written a computer program (in Fortran-63) that allowed him to plot vectoral data on a map of the Pacific basin in different projections (Frankel 2012b). On a Mercator projection using the best-fit rotation pole (situated in northern Ontario), not the geographical pole, the horizontal projections of slip vectors between perfectly rigid plates should parallel the upper and lower boundaries of the map (Fig. 2). The

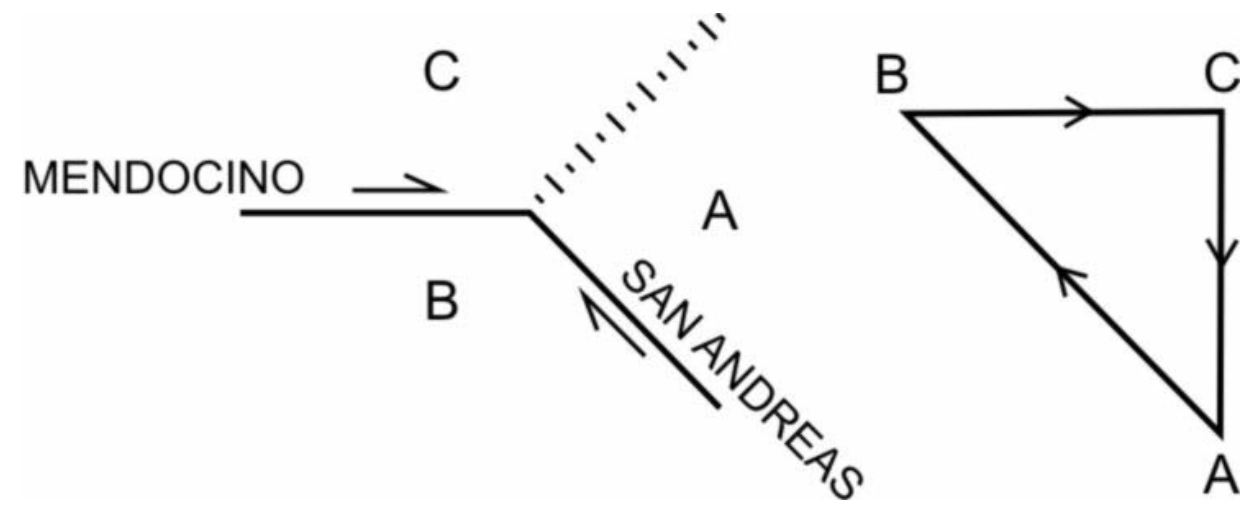

Figure 1. The existence of a third plate (C) allows simultaneous strike slip on the San Andreas and Mendocino faults, given a consuming plate margin (C-A) that sums the plate motion vectors (right) to zero. (Reprinted by permission from MacMillan Publishers Ltd: [Nature] McKenzie and Parker 1967).



Figure 2. A Mercator projection of the Pacific with a pole at $50^{\circ} \mathrm{N}, 85^{\circ} \mathrm{W}$. The arrows show the direction of motion of the Pacific plate relative to that containing North America and Kamchatka, based on earthquake slip vectors. If both plates are torsionally rigid, all the slip vectors must be parallel with each other and with the upper and lower boundaries of the figure. Possible boundaries of other plates (note Gorda-Juan de Fuca plate) are sketched. (Reprinted by permission from MacMillan Publishers Ltd: [Nature] McKenzie and Parker 1967).

projection was a stroke of genius, making the test result transparent at a glance (McKenzie and Parker 1967). What the two did not know was that Jason Morgan at Princeton University had already used Euler's theorem to test the rigidity of plates based on completely different data (Le Pichon 1991). The two papers combined made a compelling case for plate tectonics, not because the data fit perfectly (they did not), but because one test was 
based on historical earthquakes in subduction zones of the Pacific (McKenzie and Parker 1967), the other on fracture zones developed over 180 Myrs of sea-floor spreading in the Atlantic (Morgan 1968). Ironically, a more senior geophysicist at Scripps, pioneer inverse theorist George Backus, had proposed a test of Euler rotations using magnetic anomalies in the South Atlantic four years earlier (Backus 1964), but his proposal was rejected by NSF (National Science Foundation) as "too speculative" (Menard 1986). In 1967, Backus was instrumental in bringing Bob Parker to Scripps.

For Tanya, the third plate was magical. It is the eastern counterpart of the Pacific Plate, with which it shares a common spreading ridge, segmented by long-lived transform faults. It is simultaneously the plate that subducts beneath North America, giving rise to the Cascades and Mexican volcanic arcs, and which formerly subducted along the entire west coast, where extinct and deeply-eroded volcanic arcs are represented by the Mesozoic Sierra Nevada, Peninsular Ranges, Idaho and Coast Mountains batholiths. In the North Pacific, the plate has been almost entirely subducted due to the westward advance of North America as the Atlantic opened (Coney 1971; Burke and Wilson 1972). The transformation of the continental margin from a convergent plate boundary to a strike-slip boundary would have occurred at any latitude when the spreading ridge met the subduction zone, resulting in their mutual destruction. This scenario was beautifully spelled out in principle by McKenzie and Morgan (1969), who named the ancestral third plate the Farallon plate (Fig. 3). Tanya decided to see if this scenario had actually occurred in nature.

As is commonly the case in geology, the best test was a test of the timing. Did the shutdown of arc volcanism and the onset of strike-slip faulting at any latitude on land match the predicted age of ridge-trench intersection based on marine geophysical reconstruction? To actually carry out such a test, a number of unknowns would need to be resolved. First, seafloor magnetic lineations from all available sources would need to be com-


Figure 3. (a) The geometry of the Northeast Pacific at about the time of anomaly 13 (Fig. 6). All fracture zones except the Mendocino and the Murray have been omitted for simplicity. (b) Stable triple junctions at about the time of anomaly 9, formed when the East Pacific Rise met the trench off western North America. The double headed arrows show the motion of the two junctions (1) and (2) relative to the North American plate A. (c) Sketch of the vector velocity diagram for junction (1), showing that it will move north-west with the Pacific plate. (d) Similar diagram for junction (2). If relative plate motions have not changed since at least the middle Oligocene, the magnetic lineations and the present motion on the San Andreas may be used to draw the velocity diagrams to scale. (e) Such a drawing of (d) shows that the triple junction J will slowly move to the south-east relative to A. The numbers are in $\mathrm{cm} / \mathrm{yr}$ and the vector $\mathrm{AB}$ shows the direction and rate of consumption of the Farallon plate beneath the North American plate (McKenzie and Morgan 1969).

piled and correlated throughout the northeast Pacific (Fig. 4). This she did (Atwater and Menard 1968, 1970). Sec- ond, the time scale of the magnetic polarity chrons had to be established. The Heirtzler time scale simply extrap- 


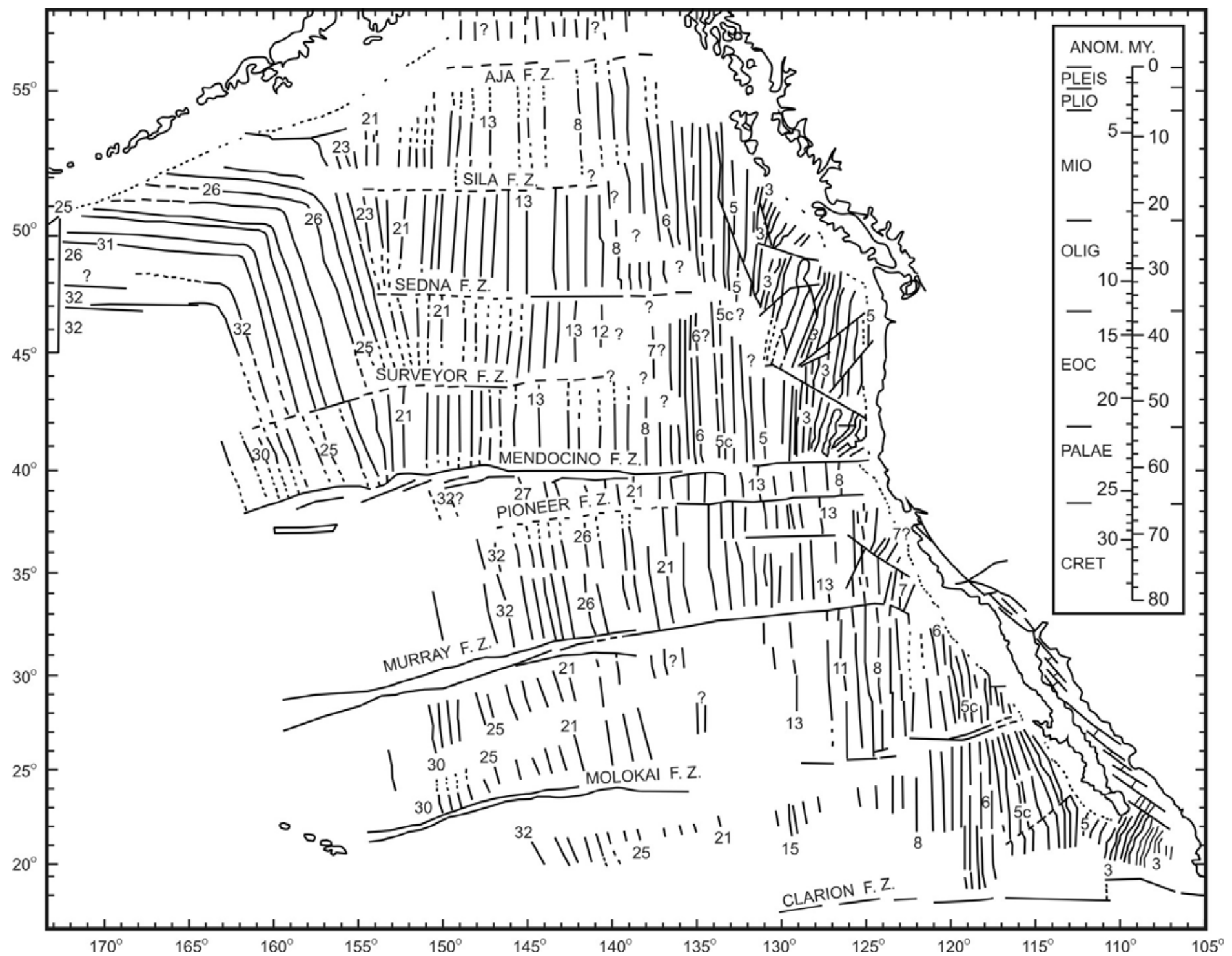

Figure 4. Magnetic anomalies in the North East Pacific (Atwater and Menard 1970), numbered according to the Heirtzler et al. (1968) time scale as calibrated by Berggren (1969).

olated spreading rates from the last 10 Myr back to the Late Cretaceous. No one had confidence that this had been true and most thought instinctively that spreading rates were slower in the past - making the Pacific basin older, at least, if not the permanent feature they had long assumed. A corollary of slower spreading was an older and more slowly slipping San Andreas Fault, about which geologists were divided. Then, good luck intervened. The deep sea drilling project JOIDES (Joint Oceanographic Institutions for Deep Earth Sampling), operated by Scripps, had risen from the ashes of the Mohole Project (killed by Republicans in Congress angered by kickbacks to Texas Democrats from Houston contractors). Its third leg was an epic 18-month cruise of the Glomar Challenger in the South Atlantic, to obtain a series of long sediment cores reaching oceanic basement along a transect normal to the Mid-Atlantic Ridge

(Maxwell et al. 1970). The results were stunning. The radiometrically calibrated ages for planktonic foraminiferal assemblages (Berggren 1969) obtained from the basal sediments increase linearly with distance from the ridge axis. This implies near-constant spreading rates since the Campanian (Late Cretaceous). The biostratigraphic ages determined for basal sediments are virtually indistinguishable from the crustal ages assigned to the drill sites in the Heirtzler time scale for magnetic polarity chrons (Maxwell et al. 1970). The Heirtzler time scale was essentially correct after all (Fig. 4).

The third unknown, the motion of the Pacific plate relative to the North American plate, ever since the Late Cretaceous, was more intractable. The solution required a plate circuit, in which histories of relative motion are determined for a series of plates, all of which are joined by spreading ridges. The plate circuit Tanya needed stepped from the Pacific to the Antarctic to the Indian (because the Southwest Indian Ridge between the Antarctic and African plates was poorly known) to the African to the North American plate. The basic methodology was laid down by Jason 
Morgan (1968) and had immediately been taken up by Xavier Le Pichon at Lamont, who alone recognized its significance and single-handedly achieved the first self-consistent global circuit model, involving six plates, before the magnetic polarity time scale was resolved (Le Pichon 1968). The problem for Tanya was that magnetic lineations in the remote South Pacific and Indian oceans were only known close to the ridge axes: the older parts of their spreading histories would not be known for years. The issue was still unresolved when Tanya wrote her 'San Andreas' paper (Atwater 1970), in which she presented two "end-member" models, one in which the present motion of the Pacific plate relative to North America was held constant and the other in which the two plates were locked together until $5 \mathrm{Ma}$. She was working on the South Pacific spreading history with post-doc Peter Molnar when we met in early 1972 (Atwater and Molnar 1973; Molnar et al. 1975; see also Stock and Molnar 1987, 1988; Atwater and Stock 1998).

The fourth and final unknown was the onland geology: where and when did the volcanic arc related to Farallon plate subduction shut down and San Andreas related strike-slip faulting begin? Tanya would need to learn enough California and west coast geology to know who to believe and who not to. She began by introducing herself to acknowledged experts like Warren Hamilton (USGS) on the arc batholiths, Peter Lipman (USGS) on Cenozoic volcanism and John Crowell (UCSB) on the San Andreas Fault system (Atwater 2001). She loved geological mapping and was soon hanging out regularly on field trips (Fig. 5). Because of the times (most geologists still had no idea in 1968 that something of major importance to their work had occurred) and because of her inclusive personality, she became a unique conduit of information between separate cultures: translating the latest results from marine geophysics in meaningful terms for geologists, and judiciously selecting for marine geophysicists the seemingly critical geological constraints.

What she learned from the geology was contradictory. Arc magmatism in the Sierra Nevada shut

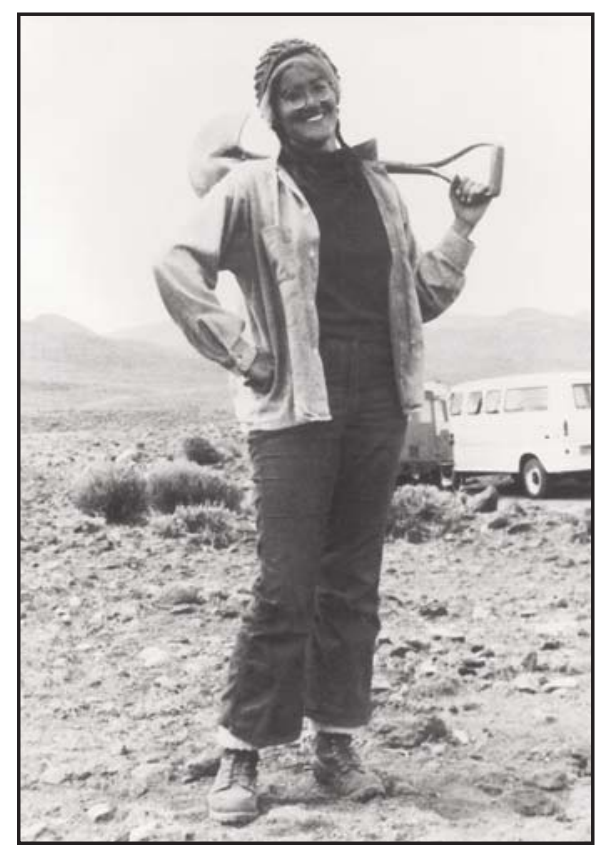

Figure 5. Tanya Atwater, circa 1975. Alan Cox photo.

down around $80 \mathrm{Ma}$ (Hamilton 1969a) but mounting evidence suggested that San Andreas displacement was much younger, starting after $30 \mathrm{Ma}$ (Crowell 1962; Addicott 1968; Matthews 1976). Late Cretaceous shut-down of the arc implied slower spreading rates in the past, while a Neogene origin for the San Andreas Fault was consistent with uniform spreading. When the Heirtzler time scale assuming fixed spreading rates was affirmed by JOIDES (Maxwell et al. 1970), the 45 Myr gap between the shut-down of the arc and the onset of San Andreas faulting became problematic. One explanation was that the Farallon slab had flattened due to buoyancy as the spreading ridge approached, causing eastward migration of the magmatic arc and widespread crustal deformation known as the Laramide orogeny (Coney and Reynolds 1977; Molnar and Atwater 1978). However, improved plate reconstructions suggested that the Laramide orogeny was too old to be accounted for in this way (Engebretson et al. 1984, 1985; Stock and Molnar 1988).

In 1970, the significance of magnetic lineations in the Northeast Pacific (discovered in the mid-1950's) had been known to marine geophysicists for only two years. Geologists were mostly focussed on one facet of California geology or another, there being no accepted conceptual framework that linked them together beyond structural evidence for a right-lateral shear couple oriented NW-SE in western North America (Carey 1958; Wise 1963; Hamilton and Myers 1966). The extended report on the historic December 1969 Penrose Conference at Asilomar (Monterey) in California on "the meaning of the new global tectonics for magmatism, sedimentation, and metamorphism in orogenic belts" (Dickinson 1970) gave no hint that marine magnetic anomalies could explain the origin and evolution of the San Andreas Fault system (Tanya had not gotten the message across in her talk at the conference). Given westward drift of North America as the Atlantic opened, the San Andreas was in fact predestined to grow from a point by the large separation in PacificFarallon spreading axes north and south of the Mendocino Fracture Zone (Fig. 6), confidently inferred from the magnetic lineations of the Northeast Pacific (McKenzie and Morgan 1969; Atwater and Menard 1970). Assuming that coast-parallel motion of the Pacific plate relative to North America had persisted since mid-Cenozoic time (her preferred model), Tanya's reconstruction (Atwater 1970) implied that Farallon plate subduction ceased and San Andreas faulting first began opposite Guaymas (Mexico), after which its intersection with the Mendocino transform fault swept rapidly northward to its present location off Cape Mendocino (westernmost California), while its intersection with the East Pacific Rise inched southward toward Mazatlán (Fig. 6). She recognized that slip on the San Andreas Fault system does not accommodate all of the displacement between the Pacific plate and cratonic North America, but that deformation extends over a broad region including the Basin and Range extensional province and the California 'borderlands', the continental shelf (Atwater 1970). The net displacement on the San Andreas Fault system is a small fraction of the net displacement of $\sim 1800 \mathrm{~km}$ between the Pacific and North American plates since $30 \mathrm{Ma}$ (Fig. 6). This is because the proto-San Andreas transform fault was situated near the continental margin until 5-6 Ma, when it 'jumped' to 

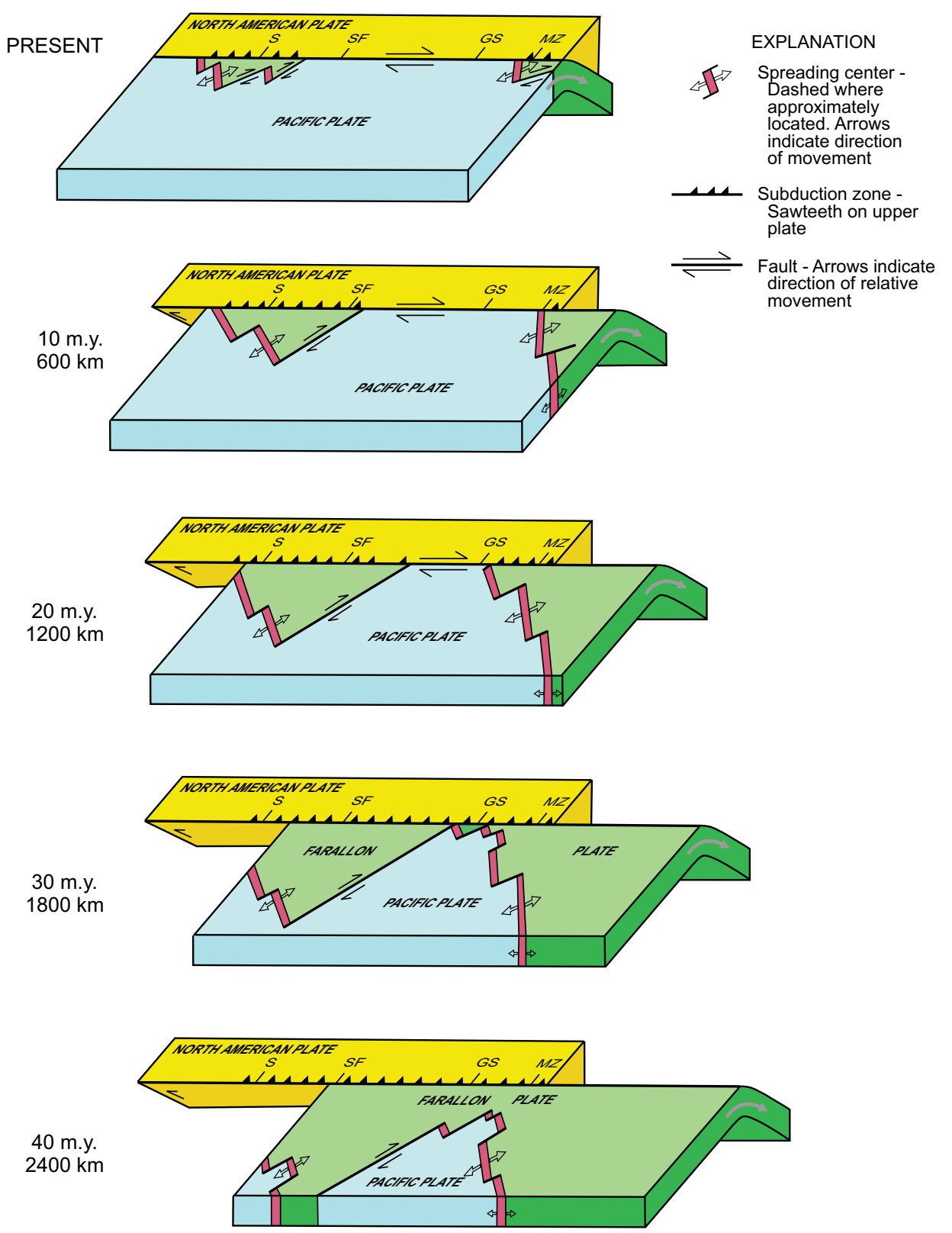

Figure 6. Sequential diagrams showing interactions between the North American, Farallon, and Pacific plates, assuming a constant relative motion of $6 \mathrm{~cm} / \mathrm{yr}$ parallel to the San Andreas Fault (modified from Atwater 1970). Position of the North American plate at each time frame shown relative to those of the Farallon and Pacific plates rather than to the outlines of the diagram. Lengthening interface between the North American and Pacific plates, shown in three upper diagrams, represents the San Andreas transform fault. Captions for each step indicate amount of time and lateral movement necessary for the North American plate to reach its present position relative to the Pacific plate. GS Guaymas; MZ, Mazatlán; S, Seattle; SF, San Francisco (Irwin 1990).

its present position along the Coast Ranges and Gulf of California (Atwater 1970). Accordingly, the present San Andreas Fault system only expresses the lion's share of Pacific-North America plate motion $(6 \mathrm{~cm} / \mathrm{yr})$ for the past 5-6 Myr, consistent with geologically estimated displacements of $<320 \mathrm{~km}$ since early Miocene time (Crowell 1962; Addicott 1968; Matthews 1976).

The East Pacific Rise was not the only spreading ridge overridden by western North America (Atwater 1970). Magnetic lineations turn east- west in the 'Great Magnetic Bight' south of the Aleutian Islands (Fig. 4), implying the existence of a fourth plate, named the Kula plate (Grow and Atwater 1970), which shared spreading ridges with the Pacific and Farallon plates and was entirely consumed at the Aleutian Trench (Pitman and Hayes 1968). The poleward motion of the Kula plate was fast, equal to the northward component of Pacific plate motion plus the spreading velocity at the Kula-Pacific ridge (Fig. 7). The Kula plate apparently broke off the Pacific and Farallon plates $\sim 85 \mathrm{Ma}$, possibly in response to Alaska-Aleutian subduction initiation (Woods and Davies 1982). Consequently, a Late Cretaceous - early Cenozoic interval of rapid $(\sim 12 \mathrm{~cm} / \mathrm{yr})$ dextral transpression between the Kula and North American plates interrupted the Farallon-North America subduction regime. Large $(\sim 2000 \mathrm{~km})$ poleward displacement (and dextral rotation) of 'Baja British Columbia', or Baja BC, the inter-montane and coastal zones of the Canadian Cordillera, occurred at this time (Beck and Noson 1972; Irving et al. 1996; Johnston et al. 1996; Enkin 2006; Enkin et al. 2006). It came as a revelation to geologists that in a system with constant plate motions, western North America had experienced abrupt yet diachronous changes in tectonic state (Fig. 7) — dextral transpression (Kula plate interaction) followed by orthogonal convergence (Farallon plate interaction) followed by dextral transtension (Pacific plate interaction). That the timing and nature of these changes at any latitude could be quantitatively predicted from marine magnetic anomalies was hard for geologists to comprehend.

In 1974, Tanya took a faculty position at MIT but found, for a second time, that she was temperamentally unsuited for eastern Massachusetts. She moved permanently to UCSB in 1980, where she continued to improve her Northeast Pacific - western North America plate model, enjoying a particularly fruitful collaboration with Joann Stock at Caltech (Atwater 1989, 1991; Atwater and Stock 1998). She poured her heart into teaching Earth science at all levels. For marine geologist Bill Menard, Tanya was not his only illustrious student-geophysicists Roger Lar- 
A.

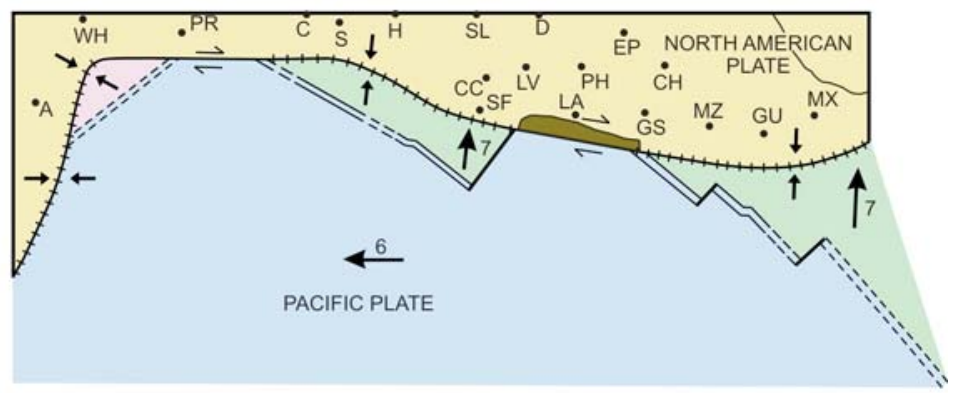

B.

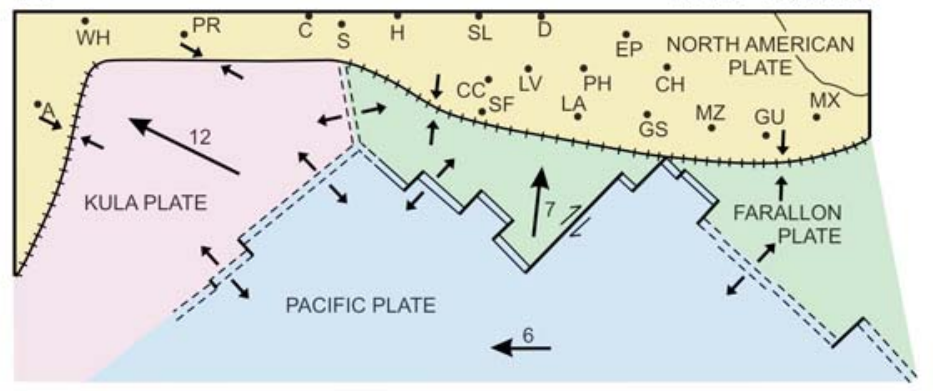

C.

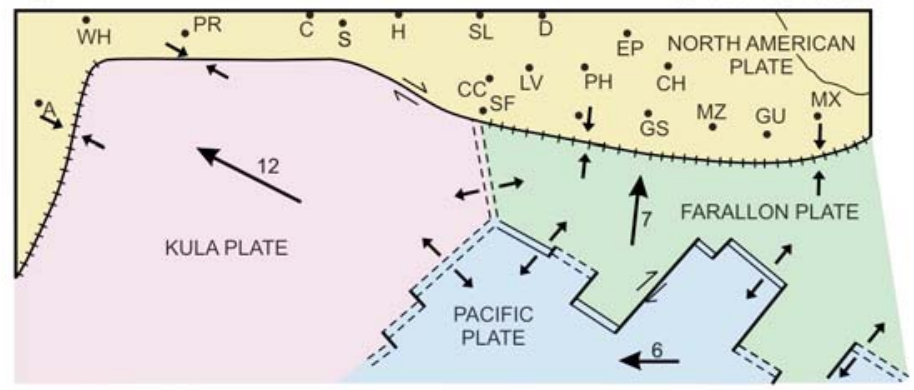

D.

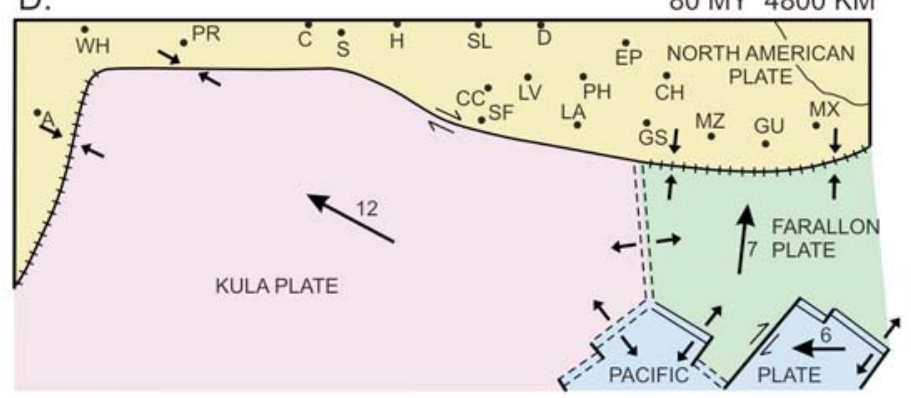

E.
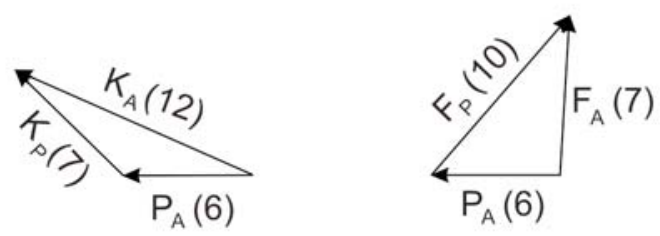

Figure 7. Plate relationships derived from extrapolation of Pacific - North America and Pacific - Kula plate motions through the Cenozoic (From Atwater 1970; fig. 18). North America is held fixed and large arrows show motion vectors relative to it. Captions give time in millions of years before present and amount of offset which must subsequently occur to bring the Pacific and North American plates to their present relative positions. Area in black is unacceptable overlap of oceanic and continental crust, indicating intraplate deformation or a minor change in Pacific - North America plate motion sometime between 20 and 40 Ma. Vector diagrams as in Fig. 1. son, Jean Francheteau, Clem Chase and Marcia McNutt are known to many. Marcia, who discovered and named the South Pacific superswell, was director of USGS (United States Geological Survey) in Obama's first presidency, heading the agency's exemplary response to the Deepwater Horizon oil spill disaster. She recently took over as editor-in-chief of the journal Science. Menard himself left an indispensable account of the plate tectonics revolution from a Scripps perspective, The Ocean of Truth (Menard 1986), before cancer cut his life short at age 65 . The book contains trenchant observations on the scientific culture at USGS, which he too directed, in the Carter administration. His observations applied equally to the GSC of that time, a culture to which I owe everything I am as a scientist.

Plate reconstruction using seafloor magnetic lineations is fundamentally limited by the rapid decrease in area of preserved oceanic crust with age. As a result, plate reconstructions relating to western North American are poorly constrained before $\sim 50 \mathrm{Ma}$ (Stock and Molnar 1988). A major source of uncertainty is the shape of the Kula-Farallon spreading ridge, which governs the timing and geographical extent of Kula-North America plate interaction (Fig. 7). Pre-Cenozoic magnetic lineations reveal the early spreading histories of the "interior" oceans (Atlantic, Indian, Southern), enabling contemporaneous PacificNorth America plate motions to be reconstructed (Seton et al. 2012). Jurassic and Cretaceous lineations in the Pacific plate imply a Farallon plate of the same antiquity which has been entirely subducted. They do not say where or when that subduction occurred.

Ever since the "new global tectonics" was first applied to the Cordillera (Hamilton 1969a; Dewey and Bird 1970; Dickinson 1970), Mesozoic and even Middle-Late Paleozoic orogenesis has been interpreted in terms of east-dipping subduction of oceanic lithosphere beneath western North America, analogous to the present volcanic central Andes (Hamilton 1969b). Accordingly, far-travelled ter- 
ranes were accreted, mainly in Jurassic time, against a west-facing subduction zone at, or close to, the North American margin (Coney 1971; Coney et al. 1980; Nokleberg et al. 2000). Shortening in the Rocky Mountain foreland to the east, mainly in Late Cretaceous Paleocene time (Laramide orogeny), occurred in a back-arc setting (Price 1981; DeCelles 2004), and variability in the depth and extent of that shortening is attributed to changing subduction dynamics (e.g. flat slab; Dewey 1980; DeCelles et al. 2009). In the Great Basin, Farallon plate subduction began after the Early Paleozoic passive margin (Bond et al. 1983) was destroyed by Middle Devonian arccontinent collision (Antler orogeny) (Dickinson 2000, 2006). Middle Devonian - Mississippian subsidence in Western Canada sedimentary basin and the adjacent Rocky Mountains is presumably a manifestation of arc-continent collision and consequent subduction flip (McKenzie 1969). Puzzles remain in this 'standard' interpretation of Cordilleran geology. What accounts for major Laramide-age shortening in the supposed back-arc all the way from Mexico to Alaska ( $\geq 170 \mathrm{~km}$ in the southern Canadian Rockies)? Conversely, why is there so little evidence of pre-Laramide (pre-125 Ma) tectonism and volcanism in the Rocky Mountains if a subduction zone existed on the continental margin at that time (Hildebrand 2009)?

From time to time, iconoclastic scenarios have been invoked to account for these and other problems with the standard model. Some scenarios postulate that the Laramide orogeny resulted from west-dipping subduction and collision of a passive North American margin with a pre-assembled arc-bearing composite terrane (Moores 1970, 1998; Tempelman-Kluit 1979; Mattauer et al. 1983; Chamberlain and Lambert 1985; Lambert and Chamberlain 1988; Johnston 2001, 2008; Johnston and Borel 2007; Hildebrand 2009, 2013). The two most recent iconoclasts, Stephen Johnston (University of Victoria) and Robert Hildebrand (University of California - Davis), arrived at nearly the same scenario independently, starting from different backgrounds and parts of the Cordillera. Stephen did his MSc with structural

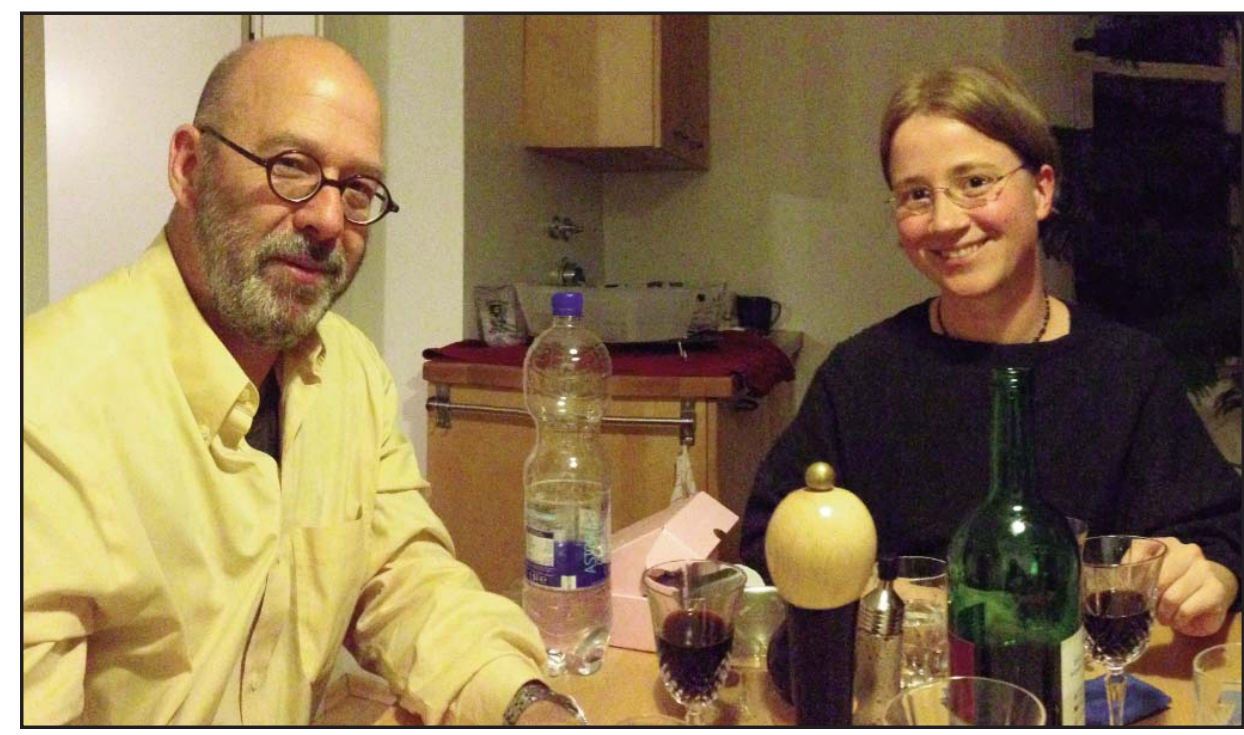

Figure 8. Stephen Johnston and Karin Sigloch in Munich, April 2013, three weeks after Karin's paper with Mitch Mihalynuk, Intra-oceanic subduction shaped the assembly of Cordilleran North America, appeared in Nature. Mitch Mihalynuk photo.

geologist Henry Charlesworth (University of Alberta), while working as an exploration geologist in the gas-rich 'triangle' zone (frontal backthrust) in the foothills of the Alberta Rockies. Charlesworth had once collected samples of Antrim Plateau basalt (Eocene) in Northern Ireland to complement Jan Hospers' paleomagnetic studies of Neogene lavas in Iceland, which had yielded the first magnetostratigraphic evidence for polarity reversals and a time-averaged geocentric axial dipole field (Hospers 1951). These discoveries, which emerged from a failed attempt to use remanent magnetic intensity as a correlation tool, gave rise to the paleomagnetic confirmation of continental drift, the interpretation of marine magnetic lineations in terms of sea-floor spreading, and the geomagnetic polarity time scale (Irving 2008; Frankel 2012a). The Antrim pole is statistically distinct from the Iceland lavas, but similar to poles from Oligocene intrusives in the Auvergne highlands of central France (Hospers and Charlesworth 1954). They had unwittingly taken the first steps towards an apparent polar wander path for Europe (Irving 2008).

Stephen's PhD thesis in southwestern Yukon (Aishihik Lake area) involved pre-Early Jurassic terrane assembly (Johnston and Erdmer 1995), but he also participated in paleomagnetic restudy of the Carmacks Group, an assemblage of 70-Ma shoshonitic lavas and volcaniclastic rocks in southwestern Yukon. The Carmacks Group provides a critical paleopole supporting the Baja BC hypothesis on account of its age and trustworthy paleohorizontal-other poles were older, placing less stringent constraints on the timing of northward motion, and most were from intrusives with no paleohorizontal (Marquis and Globerman 1988; Johnston et al. 1996; Enkin et al. 2006). The restudies confirmed that, compared with cratonic North America (Kent and Irving 2010), paleomagnetic inclinations imply $\sim 3000 \mathrm{~km}$ of northward displacement since $70 \mathrm{Ma}$, placing the Carmacks Group at the latitude of San Francisco during its eruption. It was presumably translated northward as part of the Kula plate before the latter's disappearance into the eastern Aleutian Trench $\sim 50 \mathrm{Ma}$ (DeLong et al. 1978; Bradley et al. 1993). Most Cordilleran geologists still reject the Baja BC hypothesis because they cannot find structures capable of accommodating large $(>1000 \mathrm{~km})$ dis placements of the requisite age (Price and Carmichael 1986).

After teaching on the east coast of South Africa for three years, where he worked on the Grenville-age (geon 11) orogenic belts bordering the Kaapvaal-Zimbabwe double craton, Stephen took a faculty position at University of Victoria in 1999 (Fig. 8). His 
interests are diverse: he has published on slab 'windows' and on episodicity in plume volcanism (Johnston and Thorkelson 1997, 2000). The thesis of one of his $\mathrm{PhD}$ students was on the role of sea-ice dynamics in snowball Earth climate models (Lewis et al. $2003,2004)$. His signature fascination is with oroclines (Carey 1955, 1958), particularly oroclines in which island arcs, or island arcs built on continental 'ribbons', converged head-on with subduction zones, causing them to 'jacknife' in the horizontal plane (Johnston et al. 2013). He has studied an activelyforming example in the Southwest Pacific and an Eocene one in the Northeast Pacific (Johnston and Acton 2003; Johnston 2004). He is currently most engaged with the Cantabrian orocline (NW Iberia) and the greater Variscan oroclinal system of Western Europe (Gutiérrez-Alonso et al. 2012; Johnston et al. 2013). His most controversial paper is The Great Alaskan Terrane Wreck: reconciliation of paleomagnetic and geological data in the northern Cordillera (Johnston 2001), in which northern and central Alaska are interpreted as tight oroclinal buckles at the leading end of an originally linear 'ribbon continent' driven $\geq 3000 \mathrm{~km}$ northward relative to cratonic North America between 80 and $50 \mathrm{Ma}$. He named the ribbon continent SAYBIA (SiberiaAlaska-Yukon-British Columbia). The oroclinal interpretation is testable paleomagnetically and structurally: tectonic 'facing' directions should be opposed in adjacent segments. When I attended the Yukon Geoscience Forum in January 2005, my suggestion that the paper (Johnston 2001) might live up to its title was met with derision, without falsification.

Stephen himself did not attend the Whitehorse forum because he was in Lausanne (Switzerland) as an invited professor, working on a remarkable paper with Gilles Borel, director of the geological museum of the canton (province) of Vaud. Using the tropical Tethyan affinity of fusilinid and other fauna in Permian $(\sim 280$ $\mathrm{Ma})$ seamount carbonates of the Cache Creek terrane in the intermontane Canadian Cordillera, they explored potential tectonic translation paths (Fig. 9), assuming average plate velocities of $1 \% / \operatorname{Mrr}(11 \mathrm{~cm} / \mathrm{yr})$. The paths



Figure 9. Paleogeographic map of the Earth at $280 \mathrm{Ma}$ (Stampfli and Borel 2002). The Tethys Sea (blue) separates the Laurasia (north) and Gondwana (south) components of Pangea (green). The tropical zone is indicated through the uncoloured Panthalassa superocean and the Tethys Sea. Two velocity nets, one constructed for the period 280-230 Ma and the second for 230-150 Ma are shown. The velocity nets define the potential translation paths for the Cache Creek seamounts (Johnston and Borel 2007). Bold lines indicate the limits for the locations of (a) seamount accretion to Stikinia-Quesnellia at $230 \mathrm{Ma}$ (a point on this curve in the northernmost tropics is then used as the point of origin for the 230-150 Ma net); (b) the intermontane terranes and Cassiar platform at $180 \mathrm{Ma}$, upon cessation of exhumation subsequent to Triassic orogenesis; and (c) the same terranes at $150 \mathrm{Ma}$, the time of drowning of the passive margin of western North America (Fernie Group - Morrison Formation), and the first flux of westerly(?) derived orogenic sediments onto the autochthon (Johnston and Borel 2007).

are constrained by the accretion of the seamounts $\sim 230 \mathrm{Ma}$ to the StikiniaQuesnellia magmatic arc situated in western Panthalassa, $>4000 \mathrm{~km}$ west of North America, and their collective accretion to the inferred pericratonic Nisling terrane $\sim 180 \mathrm{Ma}$ and to North America itself by Late Jurassic (Fernie Group) time (Johnston and Borel 2007). Their "Odyssey of the Cache Creek terrane" implies repeated subduction of large oceanic slabs in western tropical Panthalassa between 280 and $150 \mathrm{Ma}$. They speculated that if this cold material slowly sank to the core-mantle boundary (CMB), conductive heat transfer out of the core would quicken, giving rise to a surge in intraplate volcanism in the Pacific Basin known as the mid-Cretaceous 'superplume' (Lar- son 1991) and its 'memory', the Pacific superswell (McNutt and Judge 1990). The viability of these connections depends on the transit times of slabs to the $\mathrm{CMB}$ and plumes to the surface. They contended (Johnston and Borel 2007) that "westward subduction of oceanic lithosphere, starting at $180 \mathrm{Ma}$, that was part of the same plate as Pangea, closed the ocean basin separating the supercontinent from the terranes amalgamated within Panthalas$s a "$, and they speculate that slab pull associated with this subduction contributed to the breakup of Pangea. At this point, Stephen and I had never met, so I invited him to Harvard for a departmental seminar, in hopes that seismic tomographers in Cambridge might rise to the challenge of imaging the former intra-Panthalassic slab 
graveyard.

The timing of the collision between SAYBIA and North America presented Stephen with a dilemma. He recognized the difficulties in reconciling a Farallon flat slab with the age (too old), strike-length $(6000 \mathrm{~km})$ and magnitude $(>170 \mathrm{~km}$ of shortening in the Alberta Rockies) of foreland deformation between 85 and $50 \mathrm{Ma}$, yet he accepted that foreland basin subsidence and sedimentation began in the Late Jurassic with the Fernie Group (Poulton 1989; Leckie and Smith 1992; Ross et al. 2005), and on that basis he took $150 \mathrm{Ma}$ as the onset of SAYBIA - North America collision (Johnston and Borel 2007; Johnston 2008). Interestingly, although the Fernie Group contains detritus reworked from older sandstones (Triassic-Ordovician) within the Alberta Basin succession, detritus from juvenile crustal sources (initial $\left.\varepsilon_{\mathrm{Nd}}>-6\right)$ does not appear in the foreland basin until the Early Cretaceous (Albian, 113-100 Ma) Blairmore Group (Leckie and Smith 1992; Ross et al. 2005).

When Stephen was a fourthyear undergraduate at McGill in 1983, he had attended a day-long mini-conference hosted by the geology department on Proterozoic Plate Tectonics: A Symposium on Wopmay Orogen. The featured speakers I invited were John Grotzinger, Rein Tirrul, Janet King, Mike Easton, André Lalonde, Marc StOnge, and Rob Hildebrand. Rob had impressed me in 1975 on a mid-winter field trip he organized into the Inner Gorge of the Grand Canyon, a trip described from another participant's perspective in Gabrielle Walker's book Snowball Earth (Walker 2003). He was a third-year undergraduate at UCSB with experience in Tertiary volcanics and I was looking for an extra (non-salaried) field assistant to help map the East Arm of Great Slave Lake (Hoffman 2012b). He proved to be an insightful mapper with a knack for synthesis. His subsequent $\mathrm{PhD}$ thesis in the Wopmay orogen with Brian Fryer at Memorial University of Newfoundland was supported by Bill Padgham, chief of the Geoscience Office in Yellowknife. He joined GSC as a research scientist shortly before the McGill mini-conference and was in Ottawa for 14 years. He mapped extensively in the Great
Bear magmatic arc, prompting visits by leading Cenozoic volcanic specialists, and in the medial zone of northern Wopmay orogen. With $\mathrm{Pb}, \mathrm{Nd}$ and $\mathrm{U}-\mathrm{Pb}$ zircon work by Mike Villeneuve, Todd Housh and Sam Bowring, he identified Hottah terrane as the older magmatic arc, built on Paleoproterozoic crust, that collided at $1882 \mathrm{Ma}$ with the passive margin of Slave craton, and within which the younger Great Bear arc subsequently developed (Hildebrand 1981; Hildebrand et al. 2010a, b; Cook 2011). I had earlier inferred such a scenario but, in the absence of $\mathrm{U}-\mathrm{Pb}$ geochronology and isotopic tracers, my inference was untested (Hoffman 1980, 2012a). Rob was the leading Paleoproterozoic specialist in the Bear-Slave region at the time of the GSC staff reductions in 1996.

Losing your dream job in your mid-40's incapacitates some and turns others demonically productive. Rob falls in the latter category, but only after a decade of recovery. He moved to Tucson (Arizona), where he worked as a professional photographer and contract exploration geologist. In Venezuela, he introduced mobilistic structural concepts to the gold-bearing Trans-Amazonian (geon 21) greenstone belts of the Guyana Shield (Hildebrand 2005). He remarried and had a daughter, who he adores. He conceived, edited and published a facsimile reissue of Lands Forlorn: The Story of an Expedition to Hearne's Coppermine River, a rare 1914 classic of northern Canadian exploration, complemented by previously unpublished letters and 180 priceless photographs by the original author (Douglas and Hildebrand 2008). Encouraged by geochronologist and Wopmay contemporary Sam Bowring (MIT), he returned to unfinished GSC work. He recently published two major papers on Wopmay orogen (Hildebrand et al. 2010a, b), a multicolour 1:500 000-scale compilation map of northern Wopmay orogen and the Coppermine homocline (Hildebrand 2011), and multicolour 1:100 000-scale bedrock geology maps of the Leith Peninsula and Calder River (NTS 86E-F) map-areas (Hildebrand in press a, b). Louise Corriveau, who brightened my 1979 field party as a student assistant, authorized

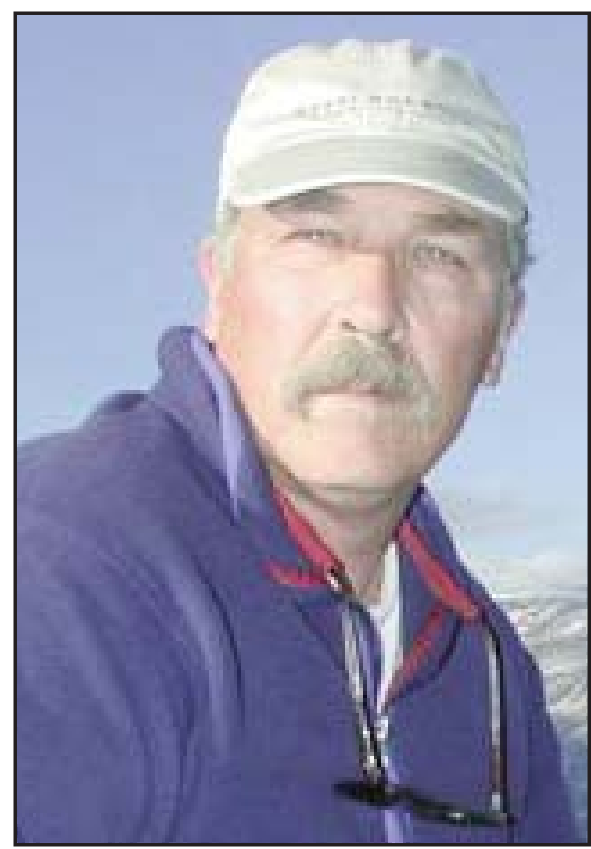

Figure 10. Rob Hildebrand in the Sierra Nevada batholith in 2010.

funding for map production. Yet, Wopmay orogen may become the answer to a trivia question: where did Hildebrand (Fig. 10) geologize before the Cordillera?

Rob's interest in the Cordillera was rekindled by a discussion with Sam Bowring, who was working with geologist Bob Miller (San Jose State University) in the North Cascades (Washington), where a complex of island arc and oceanic terranes were assembled prior to mid-Cretaceous ( $~ 96 \mathrm{Ma})$ plutonism. U-Pb dating had shown that the structurally deepest unit, the Swakane Gneiss, had been deposited at the surface less than $5 \mathrm{Myr}$ before it was metamorphosed at $27-36 \mathrm{~km}$ depth in the latest Cretaceous (Matzel et al. 2004). Field trips in California and Arizona had drawn Rob to geology in the first place, but now he looked at the Cordillera with Wopmay eyes. He had seen me compile the Precambrian geology of North America from original sources (Hoffman 1989) and he decided to do the same for the North American Cordillera, undeterred by the fact that the Cordilleran literature is 10-20 times larger, at a minimum.

Starting with the western United States and Mexico, his thinking converged, at first unknowingly, with Stephen Johnston's interpretation from 
Canada and Alaska (Johnston and Borel 2007; Johnston 2008). Like Stephen, he distinguished two continental platforms covered by shallowwater Paleozoic carbonates and clastics, separated by a deep-water basin (e.g. Selwyn basin). The outboard platform is characterized by Meso- and/or Neoproterozoic basement rocks, early Cambrian Archaeocyathid-bearing reefs, latest Cambrian - earliest Ordovician alkalic magmatism, and Permo-Triassic fauna of Tethyan affinity. It is the 'Cassiar' platform (Johnston 2008) in the north and 'Antler' platform in the south (Hildebrand 2009). They were previously conflated with the inboard platform, the true and only North American continental terrace in their view. Archean and/or late Paleoproterozoic basement underlies the 'Rocky Mountain' (Johnston 2008) or 'Sevier' (Hildebrand 2009) platform, on which early Cambrian clastics are followed by middle and upper Cambrian carbonates. The outboard platform, along with terranes to the west, experienced different magmatic and deformational histories compared with the inboard platform. There is no magmatic arc on the inboard platform, which remained virtually undeformed while the outboard platform experienced multiple episodes of orogenic deformation of late Paleozoic through Late Jurassic age (Johnston 2008; Hildebrand 2009, 2013). Conversely, tectonic thickening of the inboard platform did not begin until the Early Cretaceous (Sevier orogeny, 125-105 Ma) in the Great Basin of Nevada and adjacent states (DeCelles and Coogan 2006; Yonkee and Weil 2011), and the Late Cretaceous (Laramide orogeny, 85-50 $\mathrm{Ma}$ ) in other segments like the Canadian Rockies (Price 1981, 1994; Thompson 1981).

The Sevier orogeny is accompanied by foredeep subsidence and sedimentation in the Great Basin (Lawton et al. 2007, 2010) and an Early Cretaceous (Albian) foredeep (Blairmore Group) occurs as well in the Canadian Rockies (Leckie and Smith 1992; Ross et al. 2005). Rob interprets these Early Cretaceous deposits as marking the onset of Cordilleran foredeep subsidence and therefore the age of collision of North America with the pre-assembled outboard terranes
(Hildebrand 2009, 2013). On this point, he departs from Stephen and most previous workers, who place the onset of foredeep subsidence earlier, in the Late Jurassic. At that time, the Cordilleran foreland was invaded by fine-grained clastics of intrabasinal provenance, including the dinosaur-rich Morrison Formation in the Great Basin and the upper Fernie Group in the Canadian Rockies (Poulton 1989; Leckie and Smith 1992; Ross et al. 2005; Johnston 2008). A non-Cordilleran origin for Late Jurassic reactivation in the foreland is not inconceivable: the central North Atlantic and Gulf of Mexico rapidly opened at this time (Klitgord and Schouten 1986). Westward subduction and Cretaceous collision of North America with the composite ribbon continent was followed by northward subduction of the Kula plate and eastward subduction of the Farallon plate (minus whatever had already been subducted beneath the ribbon continent), leaving Tanya's plate tectonic model for the Cenozoic largely unassailed (Hildebrand 2009, 2013). The Cretaceous and earlier collisions are punctuated by metalliferous 'slabbreakaway' (Cloos et al. 2005) magmatic suites, most of which have been subsequently displaced to higher latitudes as part of Baja BC (Hildebrand 2009, 2013).

Rob wrote an extended critique of the standard model for Mesozoic Cordilleran tectonics, the type "Cordilleran orogen" (Dewey and Bird 1970), presenting his preferred alternative interpretation of westward subduction leading to Cretaceous collision between a passive North American margin and the composite arc-bearing ribbon continent, which he named 'Rubia' (Hildebrand 2009). The name comes from the Ruby Mountains of Nevada, where an iconic metamorphic 'core complex' was exhumed during middle Miocene extension (Colgan et al. 2010), following abortive subduction of North American crust beneath Rubia (Hildebrand 2009). GSA Books Editor Pat Bickford (Syracuse University) accepted the manuscript after critical review. Did Westward Subduction Cause Cretaceous-Tertiary Orogeny in the North American Cordillera? (Hildebrand 2009) sold out its first printing within months and, as an integrated synthesis



Figure 11. Front cover of GSA Special Paper 457 (Hildebrand 2009).

of the entire North American Cordillera, it is the best-selling GSA Special Paper ever (Fig. 11). Not every buyer was aware that it is the most radical reinterpretation of Mesozoic Cordilleran geology since the introduction of plate tectonics (Fig. 12).

On May 3rd, 2010, Rob gave a well-attended presentation of his ideas to the Cordilleran Section of GAC in Vancouver, after which he was barraged with questions for nearly 90 minutes. It is doubtful that he made any converts, but he impressed everyone with his command of the Canadian literature. Few in the audience realized that the calendar-quality scenics he used to punctuate his talk were his own creations. Not satisfied, Rob published a second GSA Special Paper (Hildebrand 2013), over twice the length of the first. It focuses on the Mesozoic assembly of Rubia and its magmatic history, particularly in California. Less polemical than Special Paper 457, it is a superb synthesis of Mesozoic Cordilleran tectonics even for those who reject a Cretaceous age for collision with North America.

The reaction to the Johnston-Hildebrand hypotheses has been curious but not unusual. Everyone thinks they know the gist of their stories, but few wish to discuss or even acknowledge them in print, whether in support or denial. It is as if they haven't passed the minimum require- 


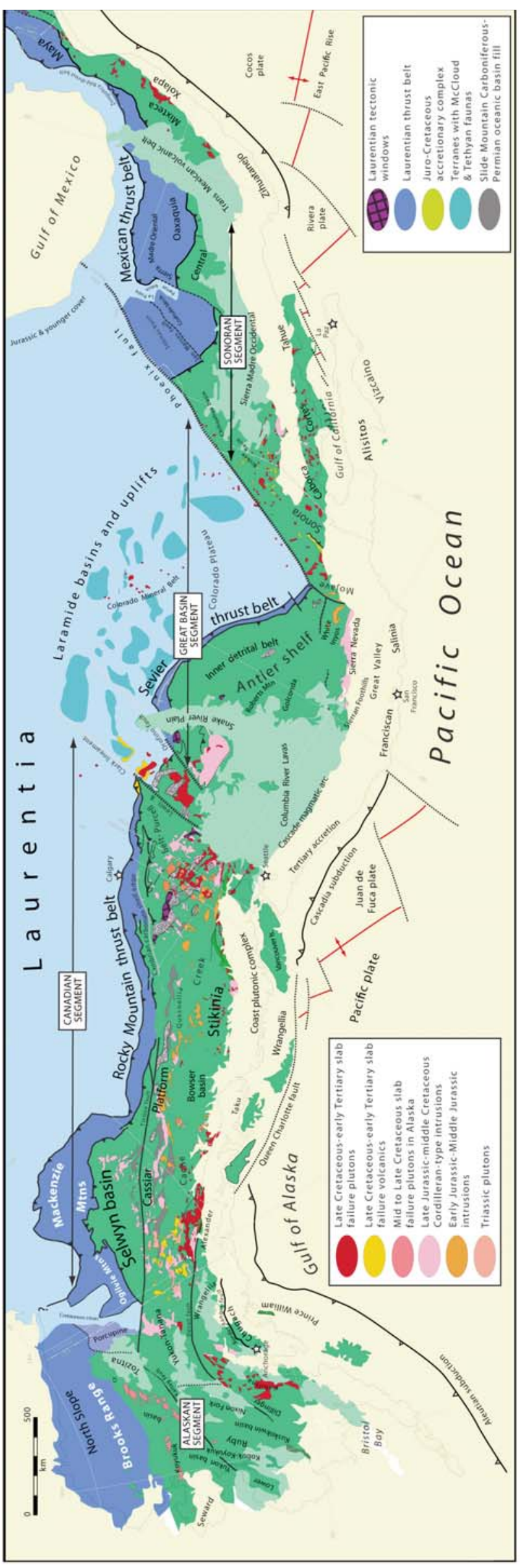

ment for recognition as legitimate scientific conjectures. The publication of Rob's synthesis as stand-alone GSA Special Papers may have contributed to this attitude, but both were peer reviewed. The situation is directly analogous to Wegener's theory of continental drift in the 1930's, which was not cited even in $\mathrm{PhD}$ theses supervised by Wegener's friend Hans Cloos. In late 2009, I attempted to publish a brief note pointing out the historical context of the JohnstonHildebrand hypotheses, with a short list of questions that might be resolved if their models were true, and new problems which would be created. The note was rejected on both sides of the Atlantic. It's wrong because we know it's wrong and anyone who doesn't must be pretty damn stupid' would be an accurate précis of the one review thought fit for my eyes. The last question in my note had been, "Can the proposed subduction bistory be reconciled with the present seismic velocity structure of the mantle beneath North America (Sigloch et al. 2008)." Seismic tomography was not an area of research I was following closely and I had slotted in different references before settling on the one by Karin Sigloch, a young seismologist at the University of Munich. Might the 3-D velocity structure of the highly viscous lower mantle (660-2900 km depth) preserve a useful record of Mesozoic oceanic plate subduction independent of crustal geology? Could it do for the older history of Cordilleran orogenesis what sea-floor magnetic anomalies had done in Tanya's day for the Cenozoic tectonics of western North America? There is hope under North America that it might. One of the major features in global tomography, the East Coast high-velocity anomaly in the mid-mantle $(600$ to $>2000 \mathrm{~km}$ depth), had long been known from low-resolution shear-velocity tomography and interpreted as a slowly-sinking mass of Farallon slab material (Grand 1987, 1994; Grand et al. 1997). Comparison of geodynamic (plate tectonic) models and tomographic models globally indicates that slab masses sink into the lower mantle more or less vertically at rates of $1-2 \mathrm{~cm} / \mathrm{yr}$, but they do so as 'walls' that are on the order of 600 $\mathrm{km}$ thick, an order of magnitude greater than the thickness of an ocean- 
ic slab (van der Meer et al. 2010; Steinberger et al. 2012). Where oceanic slabs descend at a high angle from a stable trench line, they meet resistance at the $660-\mathrm{km}$ discontinuity due to increased viscosity and endothermic phase change, causing the slab to fold back and forth on itself like a pleated skirt (Ribe et al. 2007). Eventually, resistance is overcome and the whole stack slowly descends under the influence of gravity. Simple arithmetic suggests that subduction at $6 \mathrm{~cm} / \mathrm{yr}$ could supply the mass of slab material needed if subduction had been continuous since the Late Triassic. The implied timescale is obviously inexact, but it serves as a reminder that the western North American margin, the presumed site of Farallon plate subduction, lay well to the east of the anomaly in the Late Triassic and lies far to the west of it today. For this reason, geodynamic (plate tectonic) modeling is necessary to interrelate crustal geology and seismic tomography (Müller et al. 1993; O'Neill et al. 2005; Steinberger and Torsvik 2008; van der Meer et al. 2010; Doubrovine et al. 2012; Seton et al. 2012; Shephard et al. 2012). Geodynamic modeling also provides a basis for calibrating material fluxes implied by the tomography. Where the slab descends toward the 660-km discontinuity at a low angle, whether due to buoyancy or slab roll-back, it tends to stagnate in the transition zone (410$660 \mathrm{~km}$ depth) and may never enter the lower mantle at all (van der Hilst and Seno 1993; Christensen 1996; Fukao et al. 2009).

With high-resolution data coming in from the NSF-funded USArray program, Karin had seized the opportunity as a seismology graduate student at Princeton University (2002-2008), "in orbit around the double star" of Guust Nolet and the late great Tony Dahlen. She developed and applied cutting-edge (multiple frequency $P$-wave) tomography and innovative data presentation to the deep mantle beneath North America (Sigloch 2008). She had come to the U.S. (as a fluently trilingual native of southwestern Germany) with a degree in electrical and computer engineering. She did her first research at Bell Labs (Murray Hill, NJ), where engineers, physicists and mathematicians talk to each other about their

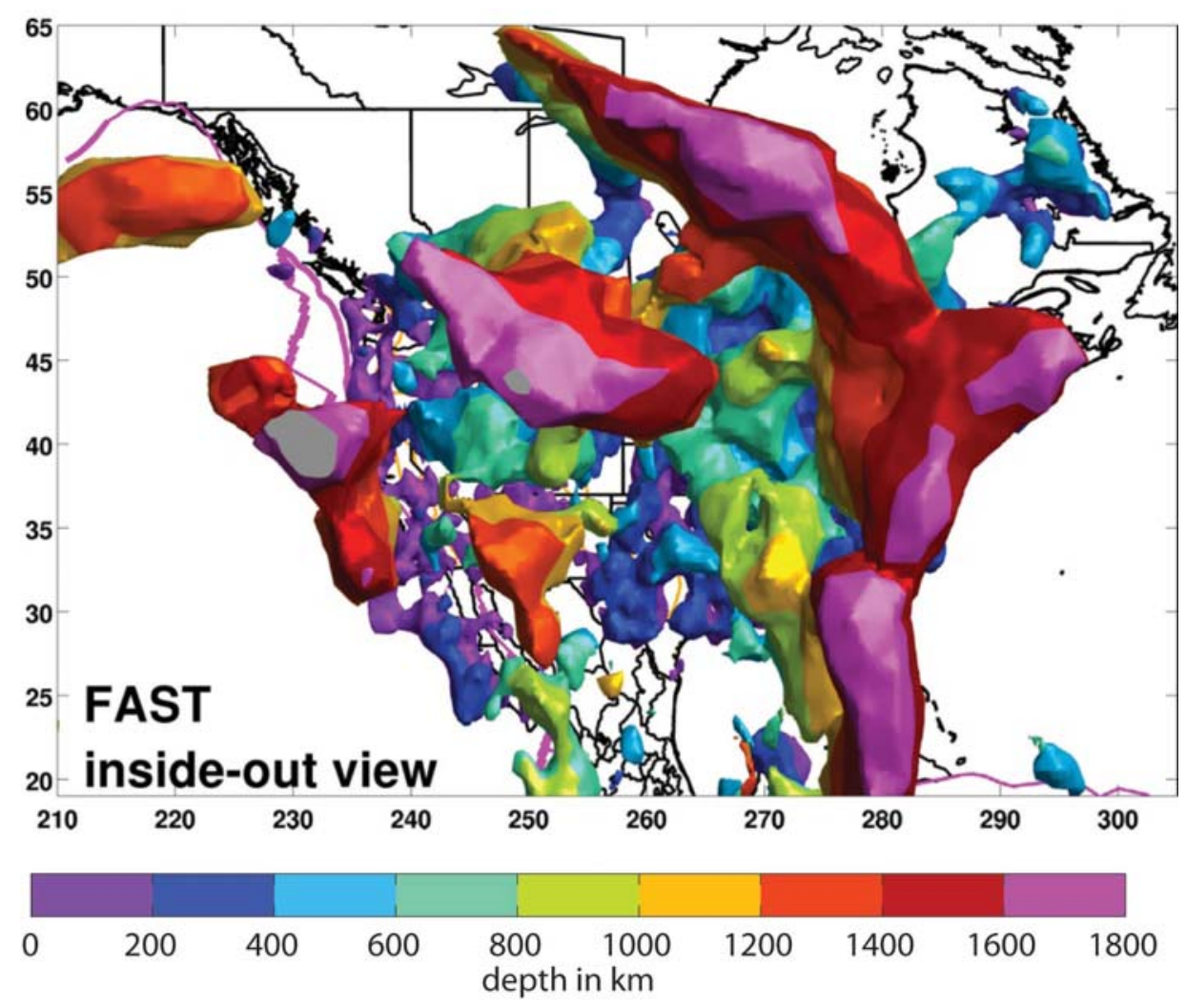

Figure 13. "Inside out" view of seismically fast (by $>0.35 \%$ ) regions (inferred slab walls) under North America, colour-banded by depth with the deepest structure emerging into the foreground (Sigloch 2011). The East Coast ('Old Farallon') anomaly is the bent structure on the right. The Cascadia anomaly is the shorter but equally deep and subvertical structure to the west, which is linked at shallow depths to the active Cascadia subduction zone (Sigloch et al. 2008). Note that fast anomalies may extend deeper than $1800 \mathrm{~km}$, the limit of resolution.

work—not having graduate studentsand no one skips lunch at the cafeteria for fear of missing an important conversation. When she started looking at grad school options, the lunch table insisted that she "had learned enough signal processing, and it was time to find a field to apply it to. A beautiful field."

I had selected Karin's PhD paper (Sigloch 2008) for my note because she recognized and discussed a second high-velocity anomaly in the mid-mantle (600 to $>2000 \mathrm{~km}$ deep) lying $1500-2000 \mathrm{~km}$ west of the wellknown East Coast, or 'Farallon anomaly' (Fig. 13). Rob van der Hilst later told me at MIT they had observed the fast anomaly centered under Yellowstone and assumed it was an artifact, because "the geology says it shouldn't be there." However, the new high-resolution $P$-wave tomography showed the new more westerly anomaly to be continuous with the active Cascadia sub- duction zone (Sigloch et al. 2008; Pavlis et al. 2012). Karin's interpretation (in 2008) provided cold comfort for the Johnston-Hildebrand hypotheses. She interpreted both anomalies in terms of an eastward subducting Farallon slab, and the gap between them as the standard Laramide flat-slab interval when the slab stagnated in the mantle transition zone (Sigloch et al. 2008). This was another reason I had selected the paper: it challenged the JohnstonHildebrand hypotheses I found attractive.

I only vaguely remembered her name three years later when I got an email announcing her talk at PGC on the Monday after the Fall 2012 AGU Meeting in San Francisco. Her title, Intra-oceanic subduction assembled Cordilleran North America, certainly got my attention. Someone on-the-ball at PGC had, in time honoured tradition, nabbed an exciting speaker who had more to convey than could be said in 
12 minutes at the Moscone Center. At the beginning of her talk, she graciously acknowledged that the model she would present for Cordilleran tectonics was based not on geology but on seismic tomography and geodynamic modeling, but that crustal geology would be the ultimate arbiter. I shifted uneasily in my chair. Then she dropped the bombshell. The great height and subvertical attitude of the East Coast ('Farallon') anomaly could not have resulted from eastward subduction at the North American continental margin, because the margin was moving rapidly westward, relative to the deep mantle, during the period when the requisite subduction had occurred. A trench tracking the migrating continent would have produced a gently inclined slab, not the thick vertical wall that she illustrated in shaded-relief, iso-velocity maps with an 'inside-out' mantle perspective (Fig. 13). Only long-lived west-dipping subduction beneath an intra-oceanic arc, situated $\sim 1500 \mathrm{~km}$ west of the Early Jurassic (preAtlantic) North American margin, could have produced the vertical pleated wall of slabs represented by the East Coast anomaly (Fig. 14). The wall is bent, with a salient to the northeast, and Karin interpreted it as a composite structure composed of multiple subduction systems and their attendant magmatic arcs and accretionary complexes, brought together at various times by prolonged intra-oceanic subduction, driven by positive feedback and distance from subduction-killing continents. As North America migrated westward, relative to the deep mantle, the continental margin 'hit' the wall of slabs, actually the trench situated above the (mid-mantle) wall, around $140 \mathrm{Ma}$ (earliest Cretaceous), according to her preferred geodynamic model (O’Neill et al. 2005). After that, subduction flipped and eastward subduction of the Farallon plate, represented by the Franciscan complex (and the Swakane gneiss) began (Fig. 14). According to her model, Cretaceous orogeny in the Cordillera was the result of collision with a long-lived intraoceanic subduction complex (Fig. 15). 'Cordilleran' orogenesis was not 'Cordilleran' in its type area. The paper she presented at AGU and more expansively at PGC appeared as an
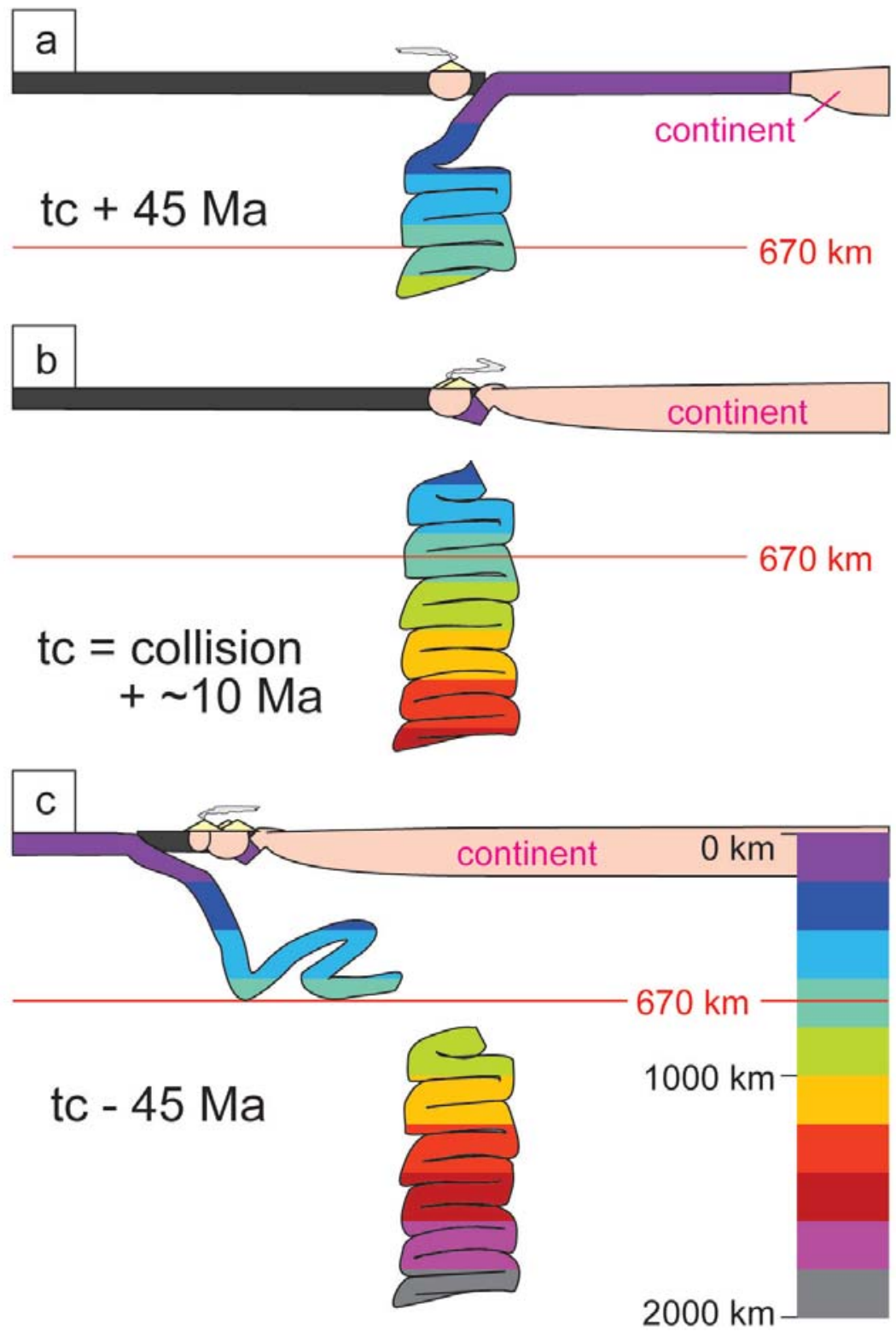

Figure 14. Schematic cross-section of an arc-continent collision and subsequent subduction flip above a vertically sinking slab wall (Sigloch and Mihalynuk 2013). Motions are shown in a lower mantle reference frame. (a) Well before the collision, both trench and arc are active. Slab buckling is due to the viscosity contrast around $670 \mathrm{~km}$ depth, but the backlog reaches into the upper mantle. (b) Around $t_{\mathrm{c}}$ and up to $\sim 10$ Myr later, the continent overrides the trench and the arc is accreted, while the slab breaks off. (c) Well after the collision, the slab wall continues to sink. Seaward, a new Andean-type subduction zone has developed. Anchored in the lower mantle, the slab wall is sinking vertically at a steady-state rate of $\sim 1.0 \mathrm{~cm} / \mathrm{yr}$ in all three panels. (Reprinted by permission from MacMillan Publishers Ltd: [Nature] Sigloch and Mihalynuk 2013).

Article in Nature the first week of April, 2013 (Sigloch and Mihalynuk 2013).

Naturally, I was curious about what prompted her about-face, from complete acceptance of the standard Cordilleran model (Sigloch et al. 2008) to one closely similar to the Johnston and Hildebrand scenarios (Sigloch and Mihalynuk 2013). Some said it was the influence of Mitch Mihalynuk, a geologist with the BC Geological Survey, who had worked with Stephen in the field and had always defended him, if not his ideas, at meetings and over beers. Mitch had initiated the collabo- 

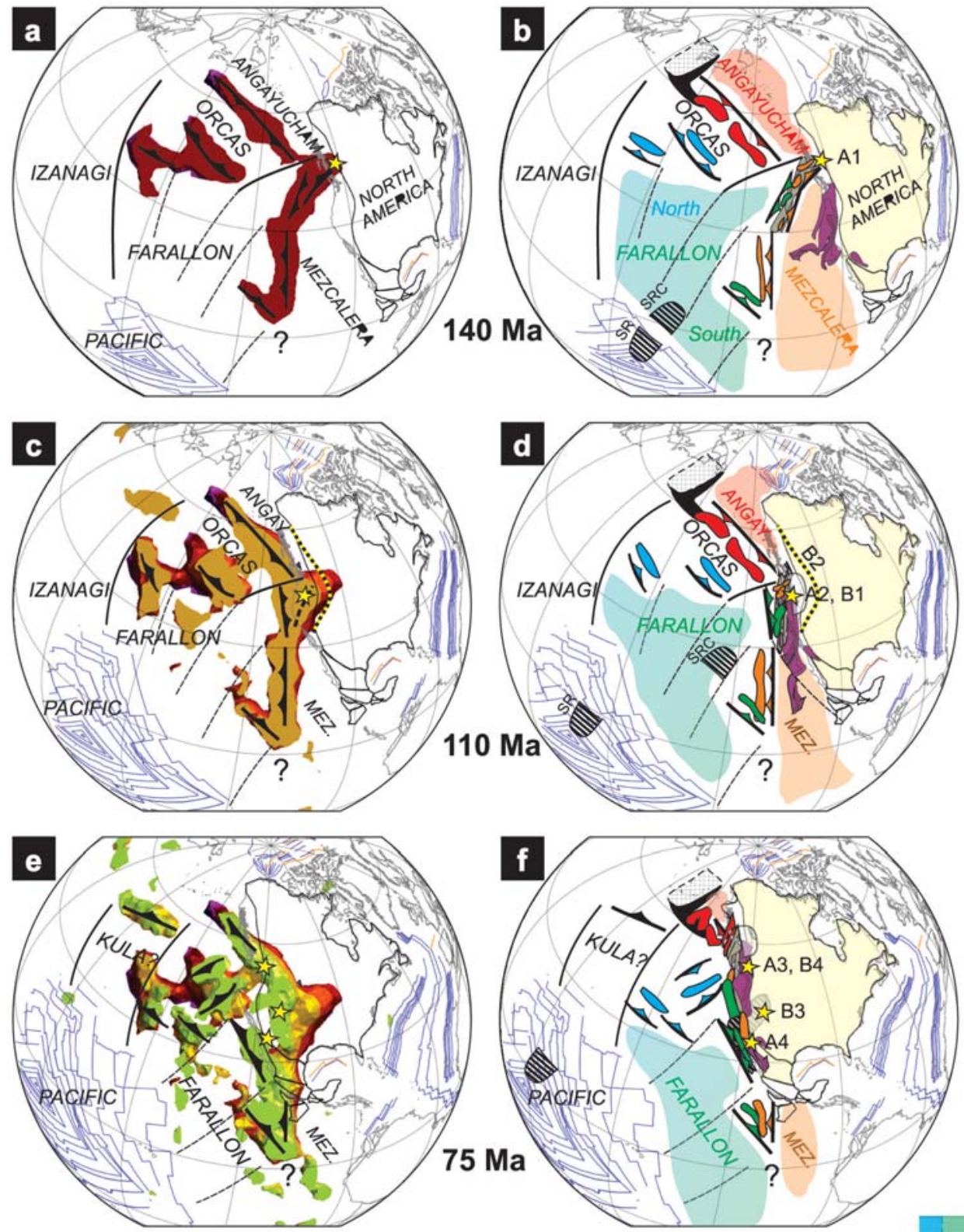

Arcs above imaged slabs

(Early Jurassic and younger)

\author{
Angayucham \\ (now interior Alaska) \\ $\checkmark$ Mezcalera \\ (younger Guerrero) \\ Cascadia/N. Farallon \\ (e.g., Siletzia) \\ Southern Farallon \\ IIII Shatsky Rise and \\ Shatsky Rise Conjugate
}

\title{
Older terranes
}

(older than mid-Jurassic)

Intermontane superterrane (IMS)

Insular superterrane (INS) (Wrangellia-Alexander)

Arctic Alaska - Seward

Angayucham plateau

\section{Other features}

is geological marker event

$\digamma$ active ridge/transform

fracture zone

? area tomographically unresolved
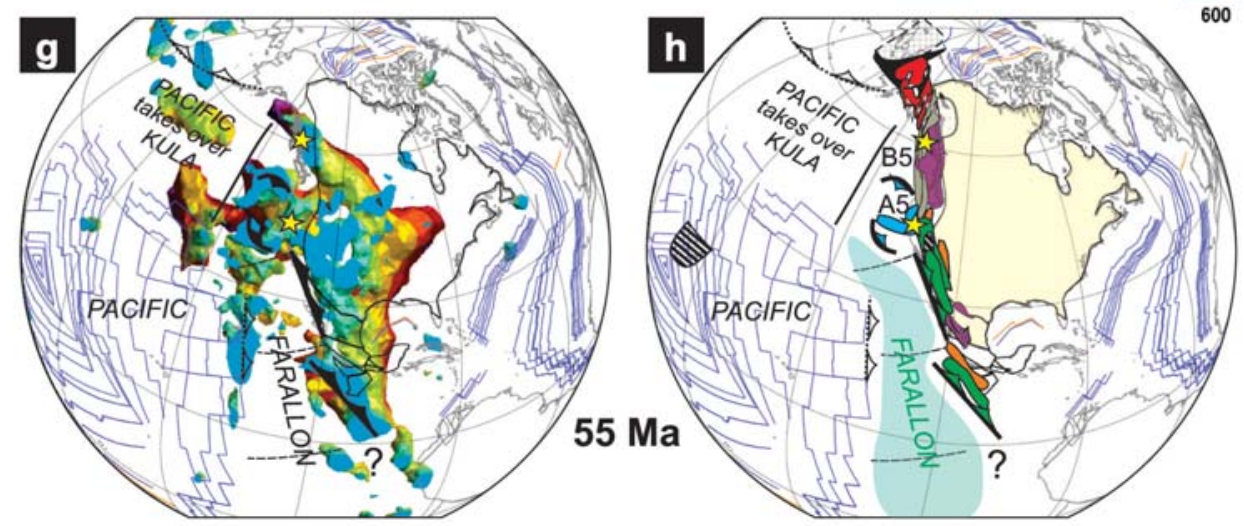

$\begin{array}{llllllll}600 & 800 & 1000 & 1200 & 1400 & 1600 & 1800 & 2000\end{array}$ depth in $\mathrm{km}$

Figure 15. Sequence of trench overrides and terrane accretions (Sigloch and Mihalynuk 2013). Left column (a, c, e, g) shows time-depth slices at 140,110, 75 and $55 \mathrm{Ma}$, showing present depths of fast anomalies of those ages and reconstructed relative locations of North America. Angayucham and Mezcalera are named segments of the 'East Coast' anomaly. Right column (b, d, $\mathrm{f}, \mathrm{h}$ ) shows interpretive cartoons of inferred trench and terrane geometries. Stars mark recognized regional tectonic events (Sigloch and Mihalynuk 2013). SR, Shatsky Rise; SRC, Shatsky Rise conjugate. (Reprinted by permission from MacMillan Publishers Ltd: [Nature] Sigloch and Mihalynuk 2013). 
ration with Karin. He had contacted her in October, 2011 because he wondered if her methodology could tell where and when subducted slabs had broken off. He considered slab breakoff to be a plausible mechanism for generating 'porphyry copper' ore deposits (Cloos et al. 2005; Hildebrand 2009). The timing of his email was critical. Dietmar Müller (University of Sydney) had been in Munich on sabbatical earlier in the year and had showed Karin what his Gplates software could do (www.earthbyte.org/Resources/earthbyte_gplates.html). They found that unless they shifted Pangea far to the west, relative to the deep mantle, they could not bring the western margin of Early Jurassic North America close to the East Coast anomaly. Karin floated the idea of intra-oceanic Cascadia subduction at a conference in September, after which Dietmar "shook his head very slightly and said I needed to talk to a terrane specialist."

Karin's first ever geological field trip in 2003 at Princeton had been to Prince Rupert with Linc Hollister, Glenn Woodsworth, Jason Morgan and Bob Phinney. She had concluded that BC was a "terrane mess", but in Mitch Mihalynuk she found a geologist she could talk to, one keenly interested in mantle processes and paleogeographic reconstruction. Did westward subduction cause Cretaceous-Tertiary orogeny on the North American Cordillera? (Hildebrand 2009) is not cited in their Nature paper (Sigloch and Mihalynuk 2013), nor are Stephen's papers in which long-lived intra-oceanic subduction is inferred geologically (Johnston and Borel 2007; Johnston 2008). His earlier paper on the Alaskan terrane-wreck is cited (Johnston 2001). After two rounds of peer review, Karin had decided that the uncited papers were not among the 50 (Nature's quota) that would satisfy the insistent geophysicist reviewers, and Mitch did not intervene. The geologist reviewer (Gary Ernst) did not mention them, perhaps because the papers had no standing in the geological community. Moreover, as Karin had stated in the introduction to her talk at PGC, the model did not stem from the geology.

A long solo-authored paper in G-cubed (Sigloch 2011) is the key to her switch, with a twist. In many ways, it is the most satisfying and at the same time arousing of her papers because it explicates the methodology, multifrequency $P$ wave tomography (Sigloch 2008), and systematically discusses each of the large-scale high- and low-velocity regions beneath North America to depths of $1800 \mathrm{~km}$. It is in this paper that she first develops the idea that a tall vertical slab wall could not have formed by subduction at a westwardmigrating continental margin. It is here that she first invokes west-dipping subduction at a stationary intra-oceanic trench, leading to collision of the continental margin with an island arc developed above the slab wall, and consequent subduction flip (Sigloch 2011). The model came strictly from integrated tomographic-geodynamic modeling, not from geology. The twist is that she did not invoke this for the East Coast anomaly, but for the 'Cascadia' anomaly beneath Yellowstone, which she here shows extending subvertically to depths beyond the limit of resolution in her tomography $(\sim 1800$ $\mathrm{km}$ ), yet is clearly continuous with present Cascadia subduction zone (Sigloch et al. 2008; Sigloch 2011; Pavlis et al. 2012). This implies a long history of near-stationary subduction prior to collision with the continental margin, which she associates with the accretion of 'Siletzia' (coastal Oregon and Washington, including the Olympic Mountains) in the Early Eocene (Brandon and Vance 1992; Dickinson 2004). She still adheres to a Farallon interpretation for the East Coast ('Old Farallon') anomaly and a stagnant flat-slab interpretation for the gap between the two deep slab walls, but her defence of Old Farallon in 2011 seems half-hearted, as if she already realized that the arguments she has just made for the deep Cascadia anomaly apply equally to Old Farallon. Where does the story go from here? To test the tomographic-geodynamic model geologically (as Karin suggested in the introduction to her talk), or to discriminate between Stephen's (Late Jurassic collision, 150 $\mathrm{Ma}$ ) and Rob's (Early Cretaceous collision, $\sim 125 \mathrm{Ma}$ ) versions, will require more precise model estimates of the timing and location where the salient of the East Coast wall (really the trench above the wall) first 'impacted' the ancient continental margin (Sevier orogeny?), and when the rest of the margin collided with the amalgamated outboard terranes (Laramide orogeny?). Many Triassic-Jurassic paleomagnetic poles for cratonic North America used in geodynamic models are from fine-grained sedimentary rocks (East North America Rift Valley System) that have 'inclination errors' due to compaction, resulting in estimated paleolatitudes that are systematically too low (Kent and Irving 2010). Applying paleopoles corrected for inclination errors will shift the locus of the initial collision southward and to a younger age, relative to the existing model (Fig. 15) (R.S. Hildebrand, personal communication). One thing is clear. Forward-looking Cordilleran geologists will engage with geodynamic modelers and seismic tomographers (e.g. Flament et al. 2013), and this will be good for all.

\section{REFERENCES}

Addicott, W.O., 1968, Mid-Tertiary zoogeographic and paleogeographic discontinuities across the San Andreas fault, California, in Dickinson, W.R., and Grantz, A., eds., Proceedings of the Conference on Geologic Problems of the San Andreas Fault System: Stanford University, Publication in the Geological Sciences, v. 11, p. 144-165.

Atwater, T., 1970, Implications of plate tectonics for the Cenozoic tectonic evolution of western North America: Geological Society of America Bulletin, v. 81, p. 3513-3536, http://dx.doi.org/10.1130/00167606(1970)81[3513:IOPTFT]2.0.CO;2.

Atwater, T., 1989, Plate tectonic history of the northeast Pacific and western North America, in Winterer, E.L., Hussong, D.M., and Decker, R.W., eds., The Eastern Pacific Ocean and Hawaii: The Geology of North America, v. N, Geological Society of America, Boulder, CO, p. 21-72.

Atwater, T., 1991, Tectonics of the Northeast Pacific: Transactions of the Royal Society of Canada, Series 1, v. 1, p. 295-318.

Atwater, T., 2001, When the plate tectonic revolution met western North America, in Oreskes, N., ed., Plate Tectonics, An Insider's History of the Modern Theory of the Earth: Westview Press, Boulder, CO, p. 243-263.

Atwater, T., and Menard, H.W., 1968, Origin and evolution of magnetic anomaly patterns in the northeast Pacific 
(abstract): Geological Society of America, Program 1968 Annual Meetings, p. 9.

Atwater, T., and Menard, H.W., 1970, Magnetic lineations in the Northeast Pacific: Earth and Planetary Science Letters, v. 7, p. 445-450,

http:/ /dx.doi.org/10.1016/0012821X(70)90089-0.

Atwater, T., and Molnar, P., 1973, Relative motion of the Pacific and North American plates deduced from seafloor spreading in the Atlantic, Indian and South Pacific oceans, in Kovach, R.L., and Nur, A., eds., Proceedings of the Conference on Tectonic Problems of the San Andreas Fault System: Stanford University, Publications in the Geological Sciences, v. 13, p. 136-148.

Atwater, T.M., and Mudie, J.D., 1968, Block faulting on the Gorda Rise: Science, v. 159, p. 729-731, http://dx.doi.org/ 10.1126/science.159.3816.729.

Atwater, T., and Stock, J., 1998, PacificNorth America plate tectonics of the Neogene southwestern United States: An update: International Geology Review, v. 40, p. 375-402, http://dx.doi.org/10.1080/002068198 09465216.

Backus, G.E., 1964, Magnetic anomalies over oceanic ridges: Nature, v. 201, p. 591-592, http://dx.doi.org/10.1038/201591a0.

Beck, M.E., Jr., Noson, L., 1972, Anomalous palaeolatitudes in Cretaceous granitic rocks: Nature, Physical Sciences, v. 235, p. 11-13, http://dx.doi.org/10.1038/physci2350 $11 \mathrm{a} 0$.

Berggren, W.A., 1969, Cenozoic chronostratigraphy, planktonic foraminiferal zonation and the radiometric time scale: Nature, v. 224, p. 1072-1075, http://dx.doi.org/10.1038/ $2241072 \mathrm{a} 0$.

Bond, G.C., Kominz, M.A., and Devlin, W.J., 1983, Thermal subsidence and eustasy in the Lower Palaeozoic miogeocline of western North America: Nature, v. 306, p. 775-779, http://dx.doi.org/10.1038/306775a0.

Bradley, D.C., Haeussler, P.J., and Kusky, T.M., 1993, Timing of early Tertiary ridge subduction in southern Alaska, in Dusel-Bacon, C., and Till, A.B., eds., Geologic Studies in Alaska by the U.S. Geological Survey, 1992: United States Geological Survey, Bulletin 2068, p. 163-173.

Brandon, M.T., and Vance, J.A., 1992, Tectonic evolution of the Cenozoic Olympic subduction complex, Washington state, as deduced from fission track ages for detrital zircons: American Journal of Science, v. 292, p. 565-636, http://dx.doi.org/ 10.2475/ajs.292.8.565.

Bullard, E., Everett, J.E., Smith, A.G., 1965, The fit of the continents around the Atlantic, in Blackett, P.M.S., Bullard, E., and Runcorn, S.K., eds., A Symposium on Continental Drift: Philosophical Transactions of the Royal Society, London, Ser. A, v. 258, p. 41-51.

Burke, K., and Wilson, J.T., 1972, Is the African plate stationary?: Nature, v. 239, p. 387-390, http://dx.doi.org/10.1038/239387b0.

Carey, S.W., 1955, The orocline concept in geotectonics, Part 1: Papers and Proceedings of the Royal Society of Tasmania, v. 89, p. 255-288.

Carey, S.W., 1958, A tectonic approach to continental drift, in Carey, S.W., ed., Continental Drift: A Symposium: Geology Department, University of Tasmania, Hobart, p. 177-355.

Chamberlain, V.E., and Lambert, R. St J., 1985, Cordilleria, a newly defined Canadian microcontinent: Nature, v. 314, p. 707-713, http://dx.doi.org/10.1038/314707a0.

Christensen, U.R., 1996, The influence of trench migration on slab penetration into the lower mantle: Earth and Planetary Science Letters, v. 140, p. 27-39, http:/ /dx.doi.org/10.1016/0012821X(96)00023-4.

Cloos, M., Sapiie, B., van Ufford, A.Q., Weiland, R.J., Warren, P.Q., and McMahon, T.P., 2005, Collisional delamination in New Guinea: The geotectonics of subducting slab breakoff: Geological Society of America Special Papers, v. 400, p. 1-51, http://dx.doi.org/10.1130/2005.2400.

Colgan, J.P., Howard, K.A., Fleck, R.J., and Wooden, J.L., 2010, Rapid middle Miocene extension and unroofing of the southern Ruby Mountains, Nevada: Tectonics, v. 29, TC6022, http://dx.doi.org/10.1029/2009TC00 2655.

Coney, P.J., 1971, Cordilleran tectonic transitions and motion of the North American plate: Nature, v. 233, p. 462-465, http://dx.doi.org/10.1038/233462a0.

Coney, P.J., and Reynolds, S.J., 1977, Cordilleran Benioff zones: Nature, v. 270, p. 403-406, http://dx.doi.org/10.1038/270403a0.

Coney, P.J., Jones, D.L., and Monger, J.W.H., 1980, Cordilleran suspect terranes: Nature, v. 288, p. 329-333, http://dx.doi.org/10.1038/288329a0.

Coode, A.M., 1965, A note on oceanic transcurrent faults: Canadian Journal of Earth Sciences, v. 2, p. 400-401, http://dx.doi.org/10.1139/e65-031.

Cook, F.A., 2011, Multiple arc development in the Paleoproterozoic Wopmay orogen, northwest Canada, in Brown, D., and Ryan, P.D., eds., Arc-Continent Collision: Frontiers in Earth Sciences: Springer-Verlag, Berlin, p. 403-427, http://dx.doi.org/10.1007/978-3-54088558-0_14.

Crowell, J.C., 1962, Displacement along the San Andreas Fault, California: Geological Society of America Special Papers, No. 71, 61 p.

DeCelles, P.G., 2004, Late Jurassic to Eocene evolution of the Cordilleran thrust belt and foreland basin system, western USA: American Journal of Science, v. 304, p. 105-168, http://dx.doi.org/10.2475/ajs.304.2.1 05.

DeCelles, P.G., and Coogan, J.C., 2006, Regional structure and kinematic history of the Sevier fold-and-thrust belt, central Utah: Geological Society of America Bulletin, v. 118, p. 841-864, http://dx.doi.org/ 10.1130/B25759.1.

DeCelles, P.G., Ducea, M.N., Kapp, P., and Zandt, G., 2009, Cyclicity in Cordilleran orogenic systems: Nature Geoscience, v. 2, p. 251-257, http://dx.doi.org/10.1038/ngeo469.

DeLong, S.E., Fox, P.J., and McDowell, F.W., 1978, Subduction of the Kula Ridge at the Aleutian Trench: Geological Society of America Bulletin, v. 89, p. 83-95, http://dx.doi.org/ 10.1130/0016-7606(1978)89 $<83$ :SOTKRA > 2.0.CO;2.

Dewey, J.F., 1980, Episodicity, sequence, and style at convergent plate boundaries, in Strangway, D.W., ed., The Continental Crust and Its Mineral Deposits: Geological Association of Canada, Special Paper 20, p. 553-573.

Dewey, J.F., and Bird, J.M., 1970, Mountain belts and the new global tectonics: Journal of Geophysical Research, v. 75 , p. 2625-2647, http://dx.doi.org/ 10.1029/JB075i014p02625.

Dickinson, W.R., 1970, Global tectonics: Science, v. 168, p. 1250-1259, http://dx.doi.org/10.1126/science.168.3936.1250.

Dickinson, W.R., 2000, Geodynamic interpretation of Paleozoic tectonic trends oriented oblique to the Mesozoic Klamath-Sierran continental margin in California, in Soreghan, M.J., and Gehrels, G.E., eds., Paleozoic and Triassic paleogeography and tectonics of western Nevada and northern California: Geological Society of America, 
Special Papers, v. 347, p. 209-245, http://dx.doi.org/10.1130/0-81372347-7.209.

Dickinson, W.R., 2004, Evolution of the North American Cordillera: Annual Reviews of Earth and Planetary Sciences, v. 32, p. 13-45,

http://dx.doi.org/10.1146/annurev.ea rth.32.101802.120257.

Dickinson, W.R., 2006, Geotectonic evolution of the Great Basin: Geosphere, v. 2, p. 353-368, http://dx.doi.org/ 10.1130/GES00054.1.

Dickson, G.O., Pitman, W.C., III, and Heirtzler, J.R., 1968, Magnetic anomalies in the South Atlantic and ocean floor spreading: Journal of Geophysical Research, v. 73, p. 2087-2100, http://dx.doi.org/10.1029/JB073i006 p02087.

Doubrovine, P.V., Steinberger, B., and Torsvik, T.H., 2012, Absolute plate motions in a reference frame defined by moving hot spots in the Pacific, Atlantic, and Indian oceans: Journal of Geophysical Research, v. 117, B09101, http://dx.doi.org/10.1029/2011JB009 072.

Douglas, G.M., and Hildebrand, R.S., 2008, Lands Forlorn: A Story of an Expedition to Hearne's Coppermine River: Zancudo Press, Tucson, AZ, 448 p.

Engebretson, D.C., Cox, A., and Thompson, G.A., 1984, Correlation of plate motions with continental tectonics: Laramide to Basin-Range: Tectonics, v. 3, p. 115-119, http://dx.doi.org/ 10.1029/TC003i002p00115.

Engebretson, D.C., Cox, A., and Gordon, R.G., 1985, Relative motions between oceanic and continental plates in the Pacific basin: Geological Society of America, Special Papers, v. 206, p. 1-60, http://dx.doi.org/ 10.1130/SPE206-p1.

Enkin, R.J., 2006, Paleomagnetism and the case for Baja British Columbia, in Haggart, J.W., Enkin, R.J., and Monger, J.W.H., eds., Paleogeography of the North American Cordillera: Evidence for and against large-scale displacements: Geological Association of Canada, Special Papers, v. 46, p. 233-253.

Enkin, R.J., Johnston, S.T., Larsen, K.P., and Baker, J., 2006, Paleomagnetism of the $70 \mathrm{Ma}$ Carmacks Group at Solitary Mountain, Yukon, confirms and extends controversial results: Further evidence for the Baja British Columbia model, in Haggart, J.W., Enkin, R.J., and Monger, J.W.H., eds., Paleogeography of the North American Cordillera: Evidence for and against large-scale displacements: Geological
Association of Canada, Special Papers, v. 46, p. 221-232.

Flament, N., Gurnis, M., and Müller, R.D., 2013, A review of observations and models of dynamic topography: Lithosphere, v. 5, p. 189-210, http://dx.doi.org/10.1130/L245.1.

Frankel, H.R., 2012a, The Continental Drift Controversy: Paleomagnetism and Confirmation of Drift Volume 2: Cambridge University Press, Cambridge, 544 p., http://dx.doi.org/ 10.1017/CBO9780511843167.

Frankel, H.R., 2012b, The Continental Drift Controversy: Evolution into Plate Tectonics, Volume 4: Cambridge University Press, Cambridge, 796 p., http://dx.doi.org/10.1017/CBO9781 139095938.

Fukao, Y., Obayashi, M., Nakakuki, T., and the Deep Slab Project Group, 2009, Stagnant slab: A review: Annual Review of Earth and Planetary Sciences, v. 37, p. 19-46, http://dx.doi.org/10.1146/annurev.ea rth.36.031207.124224.

Glen, W., 1982, The Road to Jaramillo: Critical Years of the Revolution in Earth Science: Stanford University Press, Stanford, California, 459 p.

Grand, S.P., 1987, Tomographic inversion for shear wave velocity beneath the North American plate: Journal of Geophysical Research, v. 92, p. 14065-14090, http://dx.doi.org/ 10.1029/JB092iB13p14065.

Grand, S.P., 1994, Mantle shear structure beneath the Americas and surrounding oceans: Journal of Geophysical Research, v. 99, p. 11591-11621, http://dx.doi.org/ 10.1029/94JB00042.

Grand, S.P., van de Hilst, R.D., and Widiyantoro, S., 1997, Global seismic tomography: A snapshot of convection in the Earth: GSA Today, v. 7, no. 4 , p. $1-7$.

Grow, J.A., and Atwater, T., 1970, Mid-Tertiary tectonic transition in the Aleutian Arc: Geological Society of America Bulletin, v. 81, p. 3715-3722, http://dx.doi.org/10.1130/00167606(1970)81[3715:MTTITA] 2.0.CO;2.

Gutiérrez-Alonso, G., Johnston, S.T., Weil, A.B., Pastor-Galán, D., and Fernández-Suárez, J., 2012, Buckling an orogen: The Cantabrian orocline: GSA Today, v. 22, no. 7, p. 4-9, http://dx.doi.org/10.1130/GSATG14 1A.1.

Hamilton, W.B., 1969a, Mesozoic California and the underflow of Pacific mantle: Geological Society of America Bulletin, v. 80, p. 2409-2430, http:/ /dx.doi.org/10.1130/00167606(1969)80[2409:MCATUO] 2.0.CO;2.

Hamilton, W.B., 1969b, The volcanic central Andes-A modern model for the Cretaceous batholiths and tectonics of western North America: Oregon Department of Geology and Mineral Industries Bulletin, v. 65, p. 175-184.

Hamilton, W., and Myers, W.B., 1966, Cenozoic tectonics of the western United States: Reviews of Geophysics, v. 4, p. 509-549, http://dx.doi.org/ 10.1029/RG004i004p00509.

Heirtzler, J.R., Dickson, G.O., Herron, E.M., Pitman, W.C., III, and Le Pichon, X., 1968, Marine magnetic anomalies, geomagnetic field reversals, and motions of the ocean floor and continents: Journal of Geophysical Research, v. 73, p. 2119-2136, http://dx.doi.org/10.1029/JB073i006 p02119.

Hildebrand, R.S., 1981, Early Proterozoic Labine Group of Wopmay orogen: remnant of a continental volcanic arc developed during oblique convergence, in Campbell, F.H.A., ed., Proterozoic Basins in Canada: Geological Survey of Canada, Paper 81-10, p. 133-156.

Hildebrand, R.S., 2005, Autochthonous and allochthonous strata of the El Callao greenstone belt: Implications for the nature of the Paleoproterozoic Trans-Amazonian orogeny and the origin of gold-bearing shear zones in the El Callao mining district, Guyana Shield, Venezuela: Precambrian Geology, v. 143, p. 75-86, http://dx.doi.org/10.1016/j.precamres.2005.09.009.

Hildebrand, R.S., 2009, Did westward subduction cause Cretaceous-Tertiary orogeny in the North American Cordillera?: Geological Society of America, Special Papers, v. 457, p. 1-71, http://dx.doi.org/10.1130/2009.2457.

Hildebrand, R.S., 2011, Geological synthesis, northern Wopmay orogen / Coppermine homocline, Northwest Territories - Nunavut: Geological Survey of Canada, Open File 6390; Northwest Territories Geoscience Office, Open Report 2010-011, scale 1:500 000, http://dx.doi.org/10.4095/287890.

Hildebrand, R.S., 2013, Mesozoic assembly of the North American Cordillera: Geological Society of America, Special Papers, v. 495, 169 p., http://dx.doi.org/10.1130/978081372 4959.

Hildebrand, R.S., in press a, Bedrock geol- 
ogy, Leith Peninsula (86E) map-area, Northwest Territories: Geological Survey of Canada, Open File GCM 0153, scale 1:100,000.

Hildebrand, R.S., in press b, Bedrock geology, Calder River (86F) map-area, Northwest Territories: Geological Survey of Canada, Open File GCM 0154, scale 1:100,000.

Hildebrand, R.S., Hoffman, P.F., and Bowring, S.A., 2010a, The Calderian orogeny in Wopmay orogen $(1.9 \mathrm{Ga})$, northwestern Canadian Shield: Geological Society of America Bulletin, v. 122 , p. $794-814$, http://dx.doi.org/10.1130/B26521.1.

Hildebrand, R.S., Hoffman, P.F., Housh, T., and Bowring, S.A., 2010b, The nature of volcano-plutonic relations and the shapes of epizonal plutons of continental arcs as revealed in the Great Bear magmatic zone, northwestern Canada: Geosphere, v. 6, p. 812-839, http://dx.doi.org/10.1130/ GES00533.1.

Hoffman, P.F., 1980, Wopmay orogen: a Wilson cycle of early Proterozoic age in the northwest of the Canadian Shield, in Strangway, D.W., ed., The Continental Crust and Its Mineral Deposits: Geological Association of Canada, Special Papers, v. 20, p. 523-549.

Hoffman, P.F., 1989, Precambrian geology and tectonic history of North America, in Bally, A.W., and Palmer, A.R., eds., The Geology of North America, Vol. A, The Geology of North America-An Overview: Geological Society of America, Boulder, CO, p. 447-511.

Hoffman, P.F., 2012a, The Tooth of Time: How do passive margins become active?: Geoscience Canada, v. 39, p. 67-73.

Hoffman, P.F., 2012b, The Tooth of Time: Charlie Roots: Geoscience Canada, v. 39, p. 185-194.

Hospers, J., 1951, Remanent magnetism of rocks and the history of the geomagnetic field: Nature, v. 168, p. 1111-1112, http://dx.doi.org/ 10.1038/1681111a0.

Hospers, J., and Charlesworth, H.A.K., 1954, The natural permanent magnetization of the lower basalts of Northern Ireland: Monthly Notices of the Royal Astronomical Society, v. 7, p. 32-43.

Irving, T., 2008, Jan Hosper's key contributions to geomagnetism: Eos, Transactions, American Geophysical Union, v. 89, p. 457-459, http:/ /dx.doi.org/ 10.1029/2008EO460001.

Irving, E., Wynne, P.J., Thorkelson, D.J., and Schiarizza, P., 1996, Large (1000 to $4000 \mathrm{~km}$ ) northward movements of tectonic domains in the northern Cordillera, 83 to $45 \mathrm{Ma}$ : Journal of Geophysical Research, v. 101, p. 17901-17916, http://dx.doi.org/ 10.1029/96JB01181.

Irwin, W.P., 1990, Geology and plate-tectonic development, in Wallace, R.E., ed., The San Andreas Fault System, California: United States Geological Survey, Professional Paper 1515, p. 60-80.

Isacks, B., Oliver, J., and Sykes, L.R., 1968, Seismology and the new global tectonics: Journal of Geophysical Research, v. 73 , p. $5855-5899$, http://dx.doi.org/10.1029/JB073i018 p05855.

Johnston, S.T., 2001, The Great Alaskan Terrane Wreck: reconciliation of paleomagnetic and geologic data in the northern Cordillera: Earth and Planetary Science Letters, v. 193, p. 259-272, http://dx.doi.org/ 10.1016/S0012-821X(01)00516-7.

Johnston, S.T., 2004, The New Caledonia D'Entrecasteaux orocline and its role in clockwise rotation of the Vanuatu New Hebrides Arc and formation of the North Fiji Basin, in Sussman, A.J., and Weil, A.B., eds., Orogenic curvature: Integrating paleomagnetic and structural analyses: Geological Society of America, Special Papers, v. 383, p. 225-236, http:/ /dx.doi.org/ 10.1130/0-8137-23833(2004)383[225:TNCOAП2.0.CO;2.

Johnston, S.T., 2008, The Cordilleran ribbon continent of North America: Annual Reviews of Earth and Planetary Sciences, v. 36, p. 495-530, http://dx.doi.org/10.1146/annurev.ea rth.36.031207.124331.

Johnston, S.T., and Acton, S., 2003, The Eocene Southern Vancouver Island orocline - a response to seamount accretion and the cause of fold-andthrust belt and extensional basin formation: Tectonophysics, v. 365, p. 165-183, http://dx.doi.org/ 10.1016/S0040-1951(03)00021-0.

Johnston, S.T., and Borel, G.D., 2007, The odyssey of the Cache Creek terrane, Canadian Cordillera: Implications for accretionary orogens, tectonic setting of Panthalassa, the Pacific superswell, and break-up of Pangea: Earth and Planetary Science Letters, v. 253, p. 415-428, http://dx.doi.org/ 10.1016/j.epsl.2006.11.002.

Johnston, S.T., and Erdmer, P., 1995, Hotside-up aureole in southwest Yukon and limits on terrane assembly of the northern Canadian Cordillera: Geology, v. 23, p. 419-422, http://dx.doi.org/10.1130/00917613(1995)023<0419:HSUAIS> 2.3.CO;2.

Johnston, S.T., and Thorkelson, D.J., 1997, Cocos - Nazca slab window beneath Central America: Earth and Planetary Science Letters, v. 146, p. 465-474, http://dx.doi.org/10.1016/S0012821X(96)00242-7.

Johnston, S.T., and Thorkelson, D.J., 2000, Continental flood basalts: episodic magmatism above long-lived hotspots. Earth and Planetary Science Letters, v. 175, p. 247-256, http://dx.doi.org/ 10.1016/S0012-821X(99)00293-9.

Johnston, S.T., Wynne, P.J., Francis, D., Hart, C.J.R., Enkin, R.J., and Engebretson, D.C., 1996, Yellowstone in Yukon: The Late Cretaceous Carmacks Group: Geology, v. 24, p. 997-1000, http://dx.doi.org/ 10.1130/0091-7613(1996)024 $<0997$ :YIYTLC>2.3.CO;2.

Johnston, S.T., Weil, A.B., and GutiérrezAlonso, G., 2013, Oroclines: Thick and thin: Geological Society of America Bulletin, v. 125, p. 643-663, http://dx.doi.org/10.1130/B30765.1.

Kent, D.V., and Irving, E., 2010, Influence of inclination error in sedimentary rocks on the Triassic and Jurassic apparent pole wander path for North America and implications for Cordilleran tectonics: Journal of Geophysical Research, v. 115, B10103, http://dx.doi.org/10.1029/2009JB007 205.

Klitgord, K.D., and Schouten, H., 1986, Plate kinematics of the Central Atlantic, in Vogt, P.R., and Tucholke, B.E., eds., The Western Atlantic Region: Geological Society of America, The Geology of North America, M, p. 351-378.

Kuenen, Ph.H., and Migliorini, C.I., 1950, Turbidity currents as a cause of graded bedding: The Journal of Geology, v. 58, p. 91-127, http://dx.doi.org/10.1086/625710.

Lambert, R. St J., and Chamberlain, V.E., 1988, Cordilleria revisited, with a three-dimensional model for Cretaceous tectonics in British Columbia: The Journal of Geology, v. 96, p. 47-60, http://dx.doi.org/10.1086/629192.

Larson, R.L., 1991, Latest pulse of Earth: Evidence for a mid-Cretaceous superplume: Geology, v. 19, p. 547-550, http://dx.doi.org/10.1130/00917613(1991)019<0547:LPOEEF>2.3.C $\mathrm{O} ; 2$.

Lawton, T.F., Sprinkel, D.A., and Waanders, F.L., 2007, The Cretaceous Canyon Range Conglomerate, central Utah: 
Stratigraphy, structure and significance, in Willis, G.C., Hylland, M.D., Clark, D.L., and Chidsey, T.C., Jr., eds., Central Utah-Diverse Geology of a Dynamic Landscape: Utah Geological Association, Publication 36, p. 101-122.

Lawton, T.F., Hunt, G.J., and Gehrels, G.E., 2010, Detrital zircon record of thrust belt unroofing in Lower Cretaceous synorogenic conglomerates, central Utah: Geology, v. 38, p. 463-466, http://dx.doi.org/10.1130/G30684.1.

Leckie, D.A., and Smith, D.G., 1992, Regional setting, evolution, and depositional cycles of the Western Canada foreland basin, in McQueen, R.W., and Leckie, D.A., eds., Foreland Basins and Fold Belts: American Association of Petroleum Geologists, Memoir 55, p. 9-46.

Le Pichon, X., 1968, Sea-floor spreading and continental drift: Journal of Geophysical Research, v. 73, p. 3661-3697, http://dx.doi.org/10.1029/JB073i012 p03661.

Le Pichon, X., 1986, The birth of plate tectonics: Lamont-Doherty Geological Observatory, 1985-86, Palisades, NY, p. 53-61.

Le Pichon, X., 1991, Introduction to the publication of the extended outline of Jason Morgan's April 17, 1967 American Geophysical Union paper on "Rises, trenches, great faults and crustal blocks": Tectonophysics, v. 187, p. 1-22, http:/ /dx.doi.org/ 10.1016/0040-1951(91)90407-J.

Le Pichon, X., and Heirtzler, J.R., 1968, Magnetic anomalies in the Indian Ocean and sea-floor spreading: Journal of Geophysical Research, v. 73, p. 2101-2117, http://dx.doi.org/ 10.1029/JB073i006p02101.

Lewis, J.P., Weaver, A.J., Johnston, S.T., and Eby, M., 2003, The Neoproterozoic 'snowball Earth': Dynamic sea ice over a quiescent ocean: Paleoceanography, v. 18, no. 4, 1092, http://dx.doi.org/ 10.1029/2003PA000926.

Lewis, J.P., Eby, M., Weaver, A.J., Johnston, S.T., and Jacob, R.L., 2004, Global glaciation in the Neoproterozoic: Reconciling previous modelling results: Geophysical Research Letters, v. 31, L08201, http:/dx.doi.org/ 10.1029/2004GL019725.

Marquis, G., and Globerman, B.R., 1988, Northward motion of the Whitehorse Trough: paleomagnetic evidence from the Upper Cretaceous Carmacks Group: Canadian Journal of Earth Sciences, v. 25, p. 2005-2016, http://dx.doi.org/10.1139/e88-187.
Mattauer, M., Collot, B., and Van den Driessche, J., 1983, Alpine model for the internal metamorphic zones of the North American Cordillera: Geology, v. 11, p. 11-15, http://dx.doi.org/ 10.1130/0091-7613(1983)11 $<11$ :AMFTIM>2.0.CO;2

Matthews, V., III, 1976, Correlation of Pinnacles and Neenach volcanic formations and their bearing on San Andreas Fault problem: American Association of Petroleum Geologists Bulletin, v. 60, p. 2128-2144.

Matzel, J.E.P., Bowring, S.A., and Miller, R.B., 2004, Protolith age of the Swakane Gneiss, North Cascades, Washington: Evidence of rapid underthrusting of sediments beneath an arc: Tectonics, v. 23, TC6009, http://dx.doi.org/10.1029/2003TC00 1577.

Maxwell, A.E., Von Herzen, R.P., Hsü, K.J., Andrews, J.E., Saito, T., Percival, S.F., Jr., Milow, E.D., and Boyce, R.E., 1970, Deep sea drilling in the South Atlantic: Science, v. 168, p. 1047-1059, http://dx.doi.org/10.1126/science.168.3935.1047.

McKenzie, D.P., 1969, Speculations on the consequences and causes of plate motions: Geophysical Journal International, v. 18, p. 1-32, http://dx.doi.org/10.1111/j.1365246X.1969.tb00259.x.

McKenzie, D.P., and Morgan, W.J., 1969, Evolution of triple junctions: Nature, v. 224 , p. $125-133$, http://dx.doi.org/10.1038/224125a0.

McKenzie, D.P., and Parker, R.L., 1967, The North Pacific: an example of tectonics on a sphere: Nature, v. 216, p. 1276-1280, http://dx.doi.org/ 10.1038/2161276a0.

McNutt, M.K., and Judge, A.V., 1990, The superswell and mantle dynamics beneath the South Pacific: Science, v. 248, p. 969-975, http://dx.doi.org/ 10.1126/science.248.4958.969.

Menard, H.W., 1964, Marine Geology of the Pacific: McGraw-Hill, New York, $271 \mathrm{p}$.

Menard, H.W., 1986, The Ocean of Truth: A personal history of global tectonics: Princeton University Press, Princeton, NJ, 353 p.

Menard, H.W., and Atwater, T., 1968, Changes in direction of sea floor spreading: Nature, v. 219, p. 463-467, http://dx.doi.org/10.1038/219463a0.

Menard, H.W., and Atwater, T., 1969, Origin of fracture zone topography: Nature, v. 222, p. 1037-1040, http:/ /dx.doi.org/10.1038/ $2221037 \mathrm{a} 0$.

Molnar, P., and Atwater, T., 1978, Interarc spreading and Cordilleran tectonics as alternatives related to the age of subducted oceanic lithosphere: Earth and Planetary Science Letters, v. 41, p. 330-340, http://dx.doi.org/ 10.1016/0012-821X(78)90187-5.

Molnar, P., Atwater, T., Mammerickx, J., and Smith, S.M., 1975, Magnetic anomalies, bathymetry and the tectonic evolution of the South Pacific since the Late Cretaceous: Geophysical Journal of the Royal Astronomical Society, v. 40, p. 383-420, http://dx.doi.org/ 10.1111/j.1365246X.1975.tb04139.x.

Moores, E., 1970, Ultramafics and orogeny, with models of the US Cordillera and the Tethys: Nature, v. 228, p. 837-842, http://dx.doi.org/10.1038/228837a0.

Moores, E.M., 1998, Ophiolites, the Sierra Nevada, "Cordilleria", and orogeny along the Pacific and Caribbean margins of North and South America: International Geology Review, v. 40, p. 40-54, http:/ /dx.doi.org/ 10.1080/00206819809465197.

Morgan, W.J., 1968, Rises, trenches, great faults, and crustal blocks: Journal of Geophysical Research, v. 73, p. 1959-1982, http://dx.doi.org/ 10.1029/JB073i006p01959.

Müller, R.D., Royer, J.-Y., and Lawver, L.A., 1993, Revised plate motions relative to the hotspots from combined Atlantic and Indian ocean hotspot tracks: Geology, v. 21, p. 275-278, http://dx.doi.org/10.1130/00917613(1993)021<0275:RPMRTT>2.3.C $\mathrm{O} ; 2$.

Natland, M.L., 1963, Presidential address: Paleoecology and turbidites: Journal of Paleontology, v. 37, p. 946-951.

Nokleberg, W.J., Parfenov, L.M., Monger, J.W.H., Norton, I.O., Khanchuk, A.I., Stone, D.B., Scotese, C.R., Scholl, D.W., and Fujita, K., 2000, Phanerozoic tectonic evolution of the circumnorth Pacific: United States Geological Survey, Professional Paper 1626, 122 p., http://pubs.usgs.gov/pp/2000/ 1626/pp1626.pdf.

O’Neill, C., Müller, D., and Steinberger, B., 2005, On the uncertainties in hot spot reconstructions and the significance of moving hot spot reference frames: Geochemistry, Geophysics, Geosystems, v. 6, Q04003, http://dx.doi.org/ 10.1029/2004GC000784.

Pavlis, G.L., Sigloch, K., Burdick, S., Fouch, M.J., and Vernon, F.L., 2012, Unraveling the geometry of the Farallon plate: Synthesis of three-dimensional imaging results from USArray: Tectonophysics, v. 532-535, p. 82-102, http://dx.doi.org/10.1016/j.tecto.201 
2.02.008.

Pitman, W.C., III, and Hayes, D.E., 1968, Sea-floor spreading in the Gulf of Alaska: Journal of Geophysical Research, v. 73, p. 6571-6580, http://dx.doi.org/10.1029/JB073i020 p06571.

Pitman, W.C., III, and Heirtzler, J.R., 1966, Magnetic anomalies over the PacificAntarctic Ridge: Science, v. 154, p. 1164-1171, http://dx.doi.org/ 10.1126/science.154.3753.1164.

Pitman, W.C., III, Herron, E.M., and Heirtzler, J.R., 1968, Magnetic anomalies in the Pacific and sea floor spreading: Journal of Geophysical Research, v. 73, p. 2069-2085, http://dx.doi.org/ 10.1029/JB073i006p02069.

Poulton, T.P., 1989, Upper Absoraka to Lower Zuni: The transition to the foreland basin, in Ricketts, B.D., ed., Western Canada Sedimentary Basin: Canadian Society of Petroleum Geologists, Calgary, AB, p. 233-247.

Price, R.A., 1981, The Cordilleran foreland thrust and fold belt in the southern Canadian Rocky Mountains, in McClay, K.R., and Price, N. J., eds., Thrust and nappe tectonics: Geological Society, London, Special Publications, v. 9, p. 427-448.

Price, R.A., 1994, Cordilleran tectonics and the evolution of the Western Canada sedimentary basin, in Mossop, G.D., and Shetsen, I., eds., Geological Atlas of Western Canada: Canadian Society of Petroleum Geologists/Alberta Research Council, p. 13-24.

Price, R.A., and Carmichael, D.M., 1986, Geometric test for Late Cretaceous Paleogene intracontinental transform faulting in the Canadian Cordillera: Geology, v. 14, p. 468-471, http://dx.doi.org/10.1130/00917613(1986)14<468:GTFLCI> 2.0.CO;2.

Ribe, N.M., Stutzmann, E., Ren, Y., and van der Hilst, R., 2007, Buckling instabilities of subducted lithosphere beneath the transition zone: Earth and Planetary Science Letters, v. 254, p. 173-179, http://dx.doi.org/ 10.1016/j.epsl.2006.11.028.

Ross, G.M., Patchett, P.J., Hamilton, M., Heaman, L., DeCelles, P.G., Rosenberg, E., Giovanni, M.K., 2005, Evolution of the Cordilleran orogen (southwestern Alberta, Canada) inferred from detrital mineral geochronology, geochemistry, and $\mathrm{Nd}$ isotopes in the foreland basin: Geological Society of America Bulletin, v. 117 , p. $747-763$, http://dx.doi.org/10.1130/B25564.1. Seton, M., Müller, R.D., Zahirovic, S.,
Gaina, C., Torsvik, T., Shephard, G., Talsma, A., Gurnis, M., Turner, M., Maus, S., and Chandler, M., 2012, Global continental and ocean basin reconstructions since $200 \mathrm{Ma}$ : EarthScience Reviews, v. 113, p. 212-270, http://dx.doi.org/10.1016/j.earscirev. 2012.03.002.

Shephard, G.E., Bunge, H.-P., Schuberth, B.S.A., Müller, R.D., Talsma, A.S., Moder, C., and Landgrebe, T.C.W., 2012, Testing absolute plate reference frames and the implications for the generation of geodynamic mantle heterogeneity structure: Earth and Planetary Science Letters, v. 317-318, p. 204-217, http://dx.doi.org/ 10.1016/j.epsl.2011.11.027.

Sigloch, K., 2008, Multiple-frequency body-wave tomography: Unpublished $\mathrm{PhD}$ thesis, Princeton University, Princeton, NJ, 228 p.

Sigloch, K., 2011, Mantle provinces under North America from multifrequency $P$ wave tomography: Geochemistry, Geophysics, Geosystems, v. 12, Q02W08, http://dx.doi.org/ 10.1029/2010GC003421.

Sigloch, K., and Mihalynuk, M.G., 2013, Intra-oceanic subduction shaped the assembly of Cordilleran North America: Nature, v. 496, p. 50-56, http://dx.doi.org/10.1038/nature1201 9.

Sigloch, K., McQuarrie, N., and Nolet, G., 2008, Two-stage subduction history under North America inferred from multiple-frequency tomography: Nature Geoscience, v. 1, p. 458-462, http://dx.doi.org/10.1038/ngeo231.

Stampfli, G.M., and Borel, G.D., 2002, A plate tectonic model for the Paleozoic and Mesozoic constrained by dynamic plate boundaries and restored synthetic oceanic isochrons: Earth and Planetary Science Letters, v. 196, p. 17-33, http://dx.doi.org/10.1016/S0012821X(01)00588-X.

Steinberger, B., and Torsvik, T.H., 2008, Absolute plate motions and true polar wander in the absence of hotspot tracks: Nature, v. 452, p. 620-623, http://dx.doi.org/10.1038/ nature06824.

Steinberger, B., Torsvik, T.H., and Becker, T.W., 2012, Subduction to the lower mantle - a comparison between geodynamic and tomographic models: Solid Earth, v. 3, p. 415-432, http://dx.doi.org/10.5194/se-3-4152012.

Stock, J., and Molnar, P., 1987, Revised history of early Tertiary plate motion in the south-west Pacific: Nature, v. 325, p. 495-499, http://dx.doi.org/10.1038/325495a0. Stock, J., and Molnar, P., 1988, Uncertainties and implications of the Late Cretaceous and Tertiary position of North America relative to the Farallon, Kula, and Pacific plates: Tectonics, v. 7, p. 1339-1384, http://dx.doi.org/10.1029/TC007i006 p01339.

Tempelman-Kluit, D.J., 1979, Transported cataclasite, ophiolite, and granodiorite in Yukon: evidence of arc-continent collision: Geological Survey of Canada, Paper 79-14, 27 p.

Thompson, R.I., 1981, The nature and significance of large "blind thrusts" within the northern Rocky Mountains of Canada, in McClay, K.R., and Price, N.J., eds., Thrust and nappe tectonics: Geological Society, London, Special Publications, v. 9, p. 449-462.

van der Hilst, R., and Seno, T., 1993, Effects of relative plate motion on the deep structure and penetration of slabs below the Izu-Bonin and Mariana island arcs: Earth and Planetary Science Letters, v. 120, p. 395-407, http://dx.doi.org/10.1016/0012821X(93)90253-6.

van der Meer, D.G., Spakman, W., van Hinsbergen, D.J.J., Amaru, M.L., and Torsvik, T.H., 2010, Towards absolute plate motions constrained by lowermantle slab remnants: Nature Geoscience, v. 3, p. 36-40, http://dx.doi.org/10.1038/ngeo708.

Vine, F.J., 1966, Spreading of the ocean floor: New evidence: Science, v. 154, p. 1405-1415, http://dx.doi.org/ 10.1126/science.154.3755.1405.

Vine, F.J., and Matthews, D.H., 1963, Magnetic anomalies over oceanic ridges: Nature, v. 199, p. 947-949, http://dx.doi.org/10.1038/199947a0.

Vine, F.J., and Wilson, J.T., 1965, Magnetic anomalies over a young oceanic ridge off Vancouver Island: Science, v. 150, p. 485-489, http:/ /dx.doi.org/ 10.1126/science.150.3695.485.

Walker, G., 2003, Snowball Earth: The story of a great global catastrophe that spawned life as we know it: Crown Publishers, New York, 269 p.

Walker, R.G., 1973, Mopping up the turbidite mess, in Ginsburg, R.N., ed., Evolving Concepts in Sedimentology: The Johns Hopkins University Press, Baltimore, MD, p. 1-37.

Wilson, J.T., 1965, A new class of faults and their bearing on continental drift: Nature, v. 207, p. 343-347, http://dx.doi.org/10.1038/207343a0.

Wise, D.U., 1963, An outrageous hypothesis for the tectonic pattern of the North American Cordillera: Geologi- 
cal Society of America Bulletin, v. 74, p. 357-362,

http://dx.doi.org/10.1130/00167606(1963)74[357:AOHFT'T]2.0.CO;2.

Woods, M.T., and Davies, G.F., 1982, Late Cretaceous genesis of the Kula plate: Earth and Planetary Science Letters, v. 58, p. 161-166, http://dx.doi.org/ 10.1016/0012-821X(82)90191-1.

Yonkee, W.A., and Weil, A.B., 2011, Evolution of the Wyoming salient of the Sevier fold-thrust belt, northern Utah to western Wyoming, in Sprinkel, D.A., Yonkee, W.A., and Chidsey, T.C., Jr., eds., Sevier thrust belt: northern and central Utah and adjacent areas: Utah Geological Association, Publication 40 , p. 1-56. 